OPEN ACCESS

Edited by:

Enrique Martínez-Meyer, Universidad Nacional Autónoma de México, Mexico

Reviewed by: Viorel Dan Popescu, Ohio University, United States Marcello Mezzasalma University of Naples Federico II, Italy

*Correspondence: Everton B. P. de Miranda mirandaebp@gmail.com

Specialty section:

This article was submitted to Conservation

a section of the journal

Frontiers in Ecology and Evolution

Received: 07 September 2017 Accepted: 24 November 2017 Published: 15 December 2017

Citation: Miranda EBP (2017) The Plight of Reptiles as Ecological Actors in the Tropics. Front. Ecol. Evol. 5:159. doi: 10.3389/fevo.2017.00159

\section{The Plight of Reptiles as Ecological Actors in the Tropics}

\author{
Everton B. P. de Miranda ${ }^{1,2,3 *}$ \\ ${ }^{1}$ Programa de Pós-graduação em Ecologia e Conservação da Biodiversidade, Universidade Federal de Mato Grosso, \\ Cuiabá, Brazil, ${ }^{2}$ ONF Brasil Gestão Florestal, Cotriguaçu, Brazil, ${ }^{3}$ IUCN/SSC Boa and Python Specialist Group, Buenos \\ Aires, Argentina
}

Earth's tropical ecosystems have witnessed several extinctions and a dramatic reduction of the range and abundance of large reptile species, which is directly related to the rise of early and modern humans. The occurrence of such extinctions, range reduction, species loss, and the consequences for several paramount ecosystem processes are poorly documented compared to other large vertebrate species. Here, I reviewed the literature on the ecological processes performed by large tropical reptile species and their human-induced widespread demise in order to determine knowledge gaps and encourage a paradigm shift in understanding on the interactiveness of such species. The interactions and species involved indicate that large abundant reptiles in the tropics are important in ecological processes, and can consequently have an important role in ecosystem function through gene dispersal, nutrient cycling, trophic action, and ecosystem engineering. These important interactions performed by reptiles are not solely performed by few species, or geographically restricted to islands, but instead present a pattern that repeatedly occurs in large reptiles distributed over tropical ecosystems. The observed tendency of reptiles to be tightly involved in these ecological interactions has important implications for the ecology of tropical ecosystems. Lost and current ecological processes performed by large reptiles may be orders of magnitude higher than what is currently perceived, and the misleading baseline of those processes must be addressed otherwise we risk losing species and services that are dependent of such interactions. To fix this bias I suggest: (a) Increase information spreading about Pleistocene-Holocene reptile extinctions using popular media; (b) Improved exchange between the research field of megafauna effects in ecosystems and herpetologists working with large reptiles; (c) Increase research effort on anthropogenic reptile extinctions and their potential to predict future losses; (d) Address the knowledge gaps, as human-reptile conflict, chelonian seed dispersal and nutrient movement; (e) Increase quantitative research on large reptile population ecology, density, and abundance. ( $f$ ) address the potentially present or lost ecosystem effects of extant and extinct reptile species. Although the importance of reptiles in most tropical ecosystems has been perceived as negligible, this study shows that this may be a misleading paradigm.

Keywords: crocodilians, ecosystem engineer, nutrient transport, quelonians, pollination, seed dispersal, squamates, top-down regulation 


\section{REPTILES: UNPOPULAR PLAYERS IN ECOLOGICAL PROCESSES}

Due to a set of biogeographical and institutional traits (Diamond, 1998; Acemoglu and Robinson, 2012), most of the world's developed countries are present in the northern hemisphere, as well as the majority of scientific researchers. In the biological sciences, this has resulted in a disproportionately high level of research in countries with temperate climates and low levels of biodiversity. This low level of diversity is particularly true for reptilian species-which are principally small-sized species (Makarieva et al., 2005). As the foundations of ecological theory were largely built on research based in such locations (McIntosh, 1986), there is a historical bias concerning the importance of reptiles as players in ecological processes. This perspective is epitomized by a quote concerning sagebrush lizards (Sceloporus graciosus) from Forbes magazine (Bell, 2011):

\footnotetext{
"A big remaining question is what to do about those lizards. If experts on such matters determine they're just a subspecies of the common sagebrush lizard, then to hell with them... let them just drag their scrawny tails out of the way... they're expendable."
}

The vision of reptiles as unimportant, simplistic, peripheral and expendable proto-animals remains strongly rooted in society. This vision is mirrored by the small number of tropical ecologists working on ecological processes performed by reptiles, as well as in the small attention that the subject receives. Recent efforts by Rhodin et al. (2015) and Regalado (2015) resulted in the creation of the first comprehensive compendiums on reptilian extinctions due to anthropogenic activity. Around 19\% of reptilian species are threatened, with another $21 \%$ being classed as data deficient by the IUCN. In both groups the majority of these species are present in tropical ecosystems (Böhm et al., 2013). The situation is further complicated by the disproportionate levels of research funding and attention received by charismatic species, such as felids or raptors, and the general disinterest directed toward other groups, such as amphibians, reptiles, and invertebrates (Bonnet et al., 2002).

Modern reptiles comprise today's turtles, crocodilians, snakes, amphisbaenians, lizards, tuatara, and several extinct relatives. They do not constitute a monophyletic group, since some reptiles are more closely related to birds than they are to other reptiles (Green et al., 2014). There are many groups that are now extinct, in some cases due to mass extinction events: pterosaurs, plesiosaurs, ornithischians, sauropods, many theropods, and squamates (e.g., mosasaurids) are examples (Benton, 2014). Several living subgroups are recognized (Uetz et al., 2016): Testudines (turtles and tortoises), 350 species; Amphisbaenia (amphisbaenians), 196 species; Rhynchocephalia (tuataras), 1 species; Squamata (lizards, snakes, and worm lizards), over 9,800 species; Crocodilia (crocodiles, gavials, caimans, and alligators), 25 species. Reptiles represent a great diversity of modern vertebrates.

Advances in natural history knowledge have done much to change both the academic and public perception of reptiles, and nowadays they are better understood as organisms with sophisticated adaptations for defense, predation, and migration. It is now known, for example, that reptiles can attack their prey with great strength and speed (Erickson et al., 2012), or swiftly incapacitate them using chemically complex venoms (Casewell et al., 2013). To avoid predators, reptiles can sprint over water (Aristoff et al., 2011), inject and eject poison (Triep et al., 2013), or use camouflage to match their environment (Fulgione et al., 2014). Additionally, skin colors can change to communicate fitness and emotions (Cook et al., 2013). While some reptiles can travel over $12,000 \mathrm{~km}$ using magnetic fields to navigate, others can glide through the air on membranes stretched between extended ribs (McGuire and Dudley, 2011; Hays and Scott, 2013). However, despite the discovery and public communication of such unparralled physical traits there is still little research and dissemination of the role of reptiles as promoters of ecological processes.

A shifting baseline is a change in how a system is measured, usually when compared to previous reference points, or baselines (Pauly, 1995). I argue that ecologists have, to date, failed to identify the correct baseline level of ecosystem interactiveness for tropical large reptiles (e.g., how abundant and large reptile species are or were before human exploitation). In consequence, the baseline they are working from is aberrant and misleading. In the tropics, the ecological functions of reptiles are as outstanding as their natural history traits. Reptiles in tropical ecosystems are not only biodiverse, but sometimes overwhelmingly abundant in comparison to members of other vertebrate groups (Azevedo and Murray, 2007). Abundance and large body size have long been understood as contributing to prominence in ecosystem processes (Leopold, 1949). Nonetheless, many of these highly interactive reptile species are either extinct, declining or have been extirpated over much of their range (Slavenko et al., 2016). For some reptile groups, anthropogenic extinction has already eliminated entirely distinct evolutionary orders and most of the large-sized species (Rhodin et al., 2015). Considering exclusively squamates, estimates reach as high as the extinction of 53 species globally in the last century (Alroy, 2015). I intend here to highlight the effects of past and, likely, future extinctions on ecological processes. By overcoming the former existing bias that reptiles have little ecological influence, this can help to define research and conservation priorities.

With this review I hope to catalyze a paradigm shift. My objective is to show that many reptiles have an important role in ecosystem function, clarifying conservation priorities. Specifically, I intend to accomplish this by (A) providing contemporary researchers with a single and accessible reference to the main ecological functions associated with large, abundant tropical reptiles; (B) discussing what is currently known regarding diversity loss associated with the ecological functions that reptiles perform.

\section{REPTILES AS ECOLOGICAL PLAYERS}

I intend to demonstrate the ecological importance of reptiles in four main ecological functions and processes (Figure 1): (1) The role of reptiles as gene transporters through the processes 

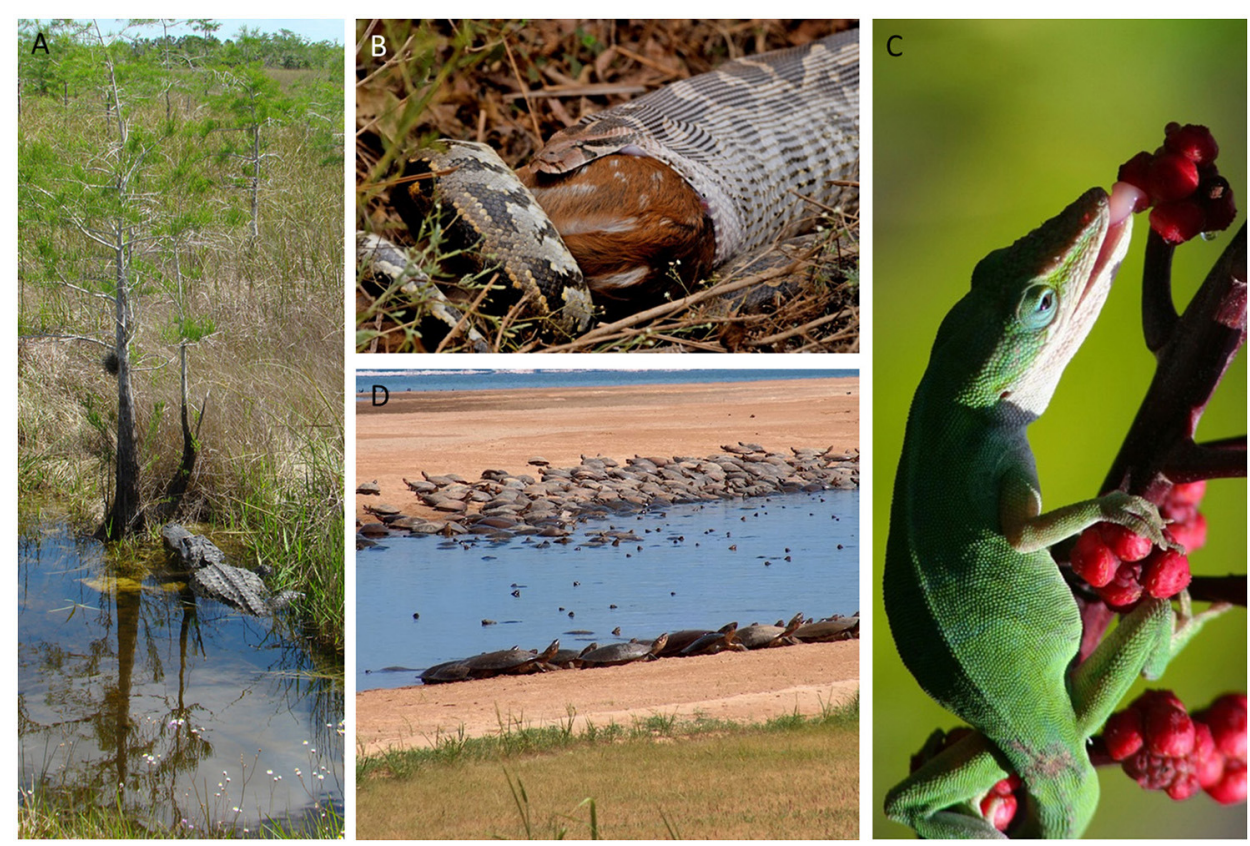

FIGURE 1 | Examples of reptiles' roles in regulating ecological processes: In (A) an alligator (Alligator mississipiensis) lies in the hole it built to spend the dry season (Palmer and Mazzotti, 2004) - as this also serves as water source to many other species, the reptile is acting as an ecosystem engineer (Photo: Anita Gould). (B) A Burmese python (Python molurus) feeds on a spotted deer (Axis axis); pythons are known to exert top down pressure (Dorcas et al., 2012), limiting prey species population sizes (Photo: Rakesh Kumar Dogra). Lizards can act as pollinators (Olesen and Valido, 2003); (C) a green anole (Anolis carolinensis) feeds on umbrella tree (Schefflera actinophylla) nectar (Photo: Leigh Hilbert). Tabuleiro do Embaubal, Brazil in (D) - Twenty thousand nesting Amazon giant river turtle (Podocnemis expansa) aggregate on this one beach each year (Miorando et al., 2015), representing a considerable nutrient input and transfer from the aquatic to terrestrial ecosystem (Photo: S. Nascimento).

of seed dispersal, pollination, and epibiosis; (2) The function of reptiles as ecosystem linkers and their involvement in the transport of nutrients from freshwater and marine ecosystems to terrestrial ones; (3) Reptiles as trophic agents through the exertion of top-down pressure on prey or vegetation, and by acting as prey themselves; (4) Reptiles as ecosystem engineers that can increase biodiversity in providing refuges or reproduction sites to other species. Finally, I discuss how to readdress the issue of the limited research effort on the ecological roles of reptiles in tropical ecosystems.

\section{Reptiles as Gene Transporters}

Pollination and seed dispersal are two fundamental aspects of plant biology in which animal involvement can both increase genetic diversity, and reduce mortality (Vranckx et al., 2012). Although seed dispersal is key to maintaining plant diversity, seed dispersal by reptiles (saurochory) is sometimes regarded as a rare phenomenon (Valido and Olesen, 2007). This notion is challenged by growing evidence of reptiles as seed dispersers (González-Castro et al., 2015), especially because of the tendency for most reptiles to gulp fruits whole, which provides little opportunity for seed damage.

South American river turtles consume fruits, and these can then be dispersed along water margins (Moll and Jansen, 1995) or carried further during long-distance migrations (Kubitzki and Ziburski, 1994). Amazon giant river turtles (Podocnemis expansa, up to $55 \mathrm{~kg}$; Smith, 1979) are known seed dispersers and migrate great distances between feeding and nesting grounds. This species was considered overwhelmingly abundant in the past (Von Humboldt, 1877), but has declined due to hunting and egg collection. All three continental tortoises in South America (Chelonoidis carbonarius, $5.9 \mathrm{~kg}$; C. chilensis $1.7 \mathrm{~kg}$; and C. denticulatus, $6.4 \mathrm{~kg}$ ) are known seed dispersers (Varela and Bucher, 2002; Strong and Fragoso, 2006). Moreover, they can reach high densities; up to 125 animals $/ \mathrm{km}^{2}$ for C. carbonarius and C. denticulatus combined (Moskovits, 1988), and go up to $54 \mathrm{~kg}$ in the largest species, C. denticulatus (Pritchard and Trebbau, 1984). The two large and widely distributed lizard genera in the Neotropics, tegu, and iguana lizards (Tupinambis and Iguana), also disperse seeds (Benítez-Malvido et al., 2003; de Castro and Galetti, 2004), and occur at high densities, reaching 83 and 122 individuals $/ \mathrm{km}^{2}$ for tegus and iguanas, respectively (Munoz et al., 2003; Bovendorp et al., 2008).

Asiatic species like the forest tortoise (Manouria emys, up to $37 \mathrm{~kg}$ ) and northern river terrapin (Batagur baska, up to $30 \mathrm{~kg}$ ) are potential seed dispersers (Standford et al., 2015) but this remains uninvestigated. Although they are the largest hardshelled chelonian species in Asia, both lack reliable population estimates, but are under extinction risk (IUCN, 2000; ATTWG, 2016). Asiatic frugivorous lizards like the Philippine varanids (Varanus bitatawa, V. mabitang, and V. olivaceus) reach up to $10 \mathrm{~kg}$ and act as seed dispersers (Bennett, 2014). All Philippine varanids are considered under risk by the IUCN (Gaulke and Demegillo, 2008). 
In Africa, the huge and widely-distributed leopard tortoise (Stigmochelys pardalis; up to $48 \mathrm{~kg}$ ), and spurred tortoise (Centrochelys sulcata; up to $93 \mathrm{~kg}$ ) are both potential seed dispersers (Milton, 1992). While the role of leopard tortoise as a seed disperser has been investigated, any effort has been made to characterize the seed dispersal potential in spurred tortoises. Reported densities of leopard tortoises reach 85 individuals $/ \mathrm{km}^{2}$ (Mason et al., 2000). There are no population records for spurred tortoise density, though wild populations in its native Sahel are now scarce, and it is considered Vulnerable (IUCN, 1996). Some smaller African reptiles, such as spiny tailed lizards (Uromastyx aegyptia, up to $3 \mathrm{~kg}$ ), are seed dispersers in desert environments (Wilms and Wagner, 2009), and can reach densities of 400 individuals $/ \mathrm{km}^{2}$ (Kordges, 1998) but suffer from extensive persecution (Figure 2C) and are considered Vulnerable by IUCN (Wilms et al., 2012).

On tropical islands, giant tortoises are frequently the main seed dispersers (Blake et al., 2012). Many of these species have already been exterminated (Rhodin et al., 2015): five became extinct after human colonization of the Pacific Ocean's Mascarene Islands (Cylindraspis triserrata, C. vosmaeri, C. peltastes, C. inepta, and C. indica), while two were lost on Madagascar (Aldabrachelys grandidieri and A. abrupta), and seven from the Caribbean archipelago (including Chelonoidis alburyorum, C. cubensis, and five other undescribed species), and four from the Galápagos (Chelonoidis abingdoni, C. nigra, C. phantastica, and Chelonoidis sp.). These past losses are currently impacting seed dispersal on the islands of Madagascar and Mauritius; respectively, baobab and ebony species are at risk due to the absence of their co-evolved chelonian dispersers (Moolna, 2008; Andriantsaralaza et al., 2014). Since 57\% of Earth's tortoises, including several large-sized continental species, were extirpated or made extinct by early or modern Homo species during the Pleistocene (Rhodin et al., 2015), similar effects in other ecosystems may have occurred or may still be occurring.

Evolutionary unique groups of giant tortoises were also eliminated during human colonization of Sahul (present New Guinea, Australia, and Tasmania, before sea levels rose). The 200 kg-plus Meiolanidae, a family of horned tortoises, were giant herbivores. Anthropogenic causes meant they had disappeared long before we could understand their ecological role in ecosystems. Insular seed disperser extinctions were not restricted to tortoises: the giant iguanas (Brachylophus gibbonsi, Lapitiguana impensa) of Tonga and Fiji archipelagos in Pacific also vanished upon human colonization, causing disruption to the island's seed dispersal ecology (Meehan et al., 2002).

Pollination by reptiles (Figure 1C), although mostly restricted to insular lizards, is a widespread phenomenon occurring on islands in all tropical seas and includes at least 50 gecko species (Godínez-Alvarez, 2004). Low abundances of insect, both as prey and pollinators, probably drove insular lizards to consume fruit pulp and nectar. This, combined with density compensation, niche expansion, and low predation pressure, has resulted in lizards being important pollinators on many island
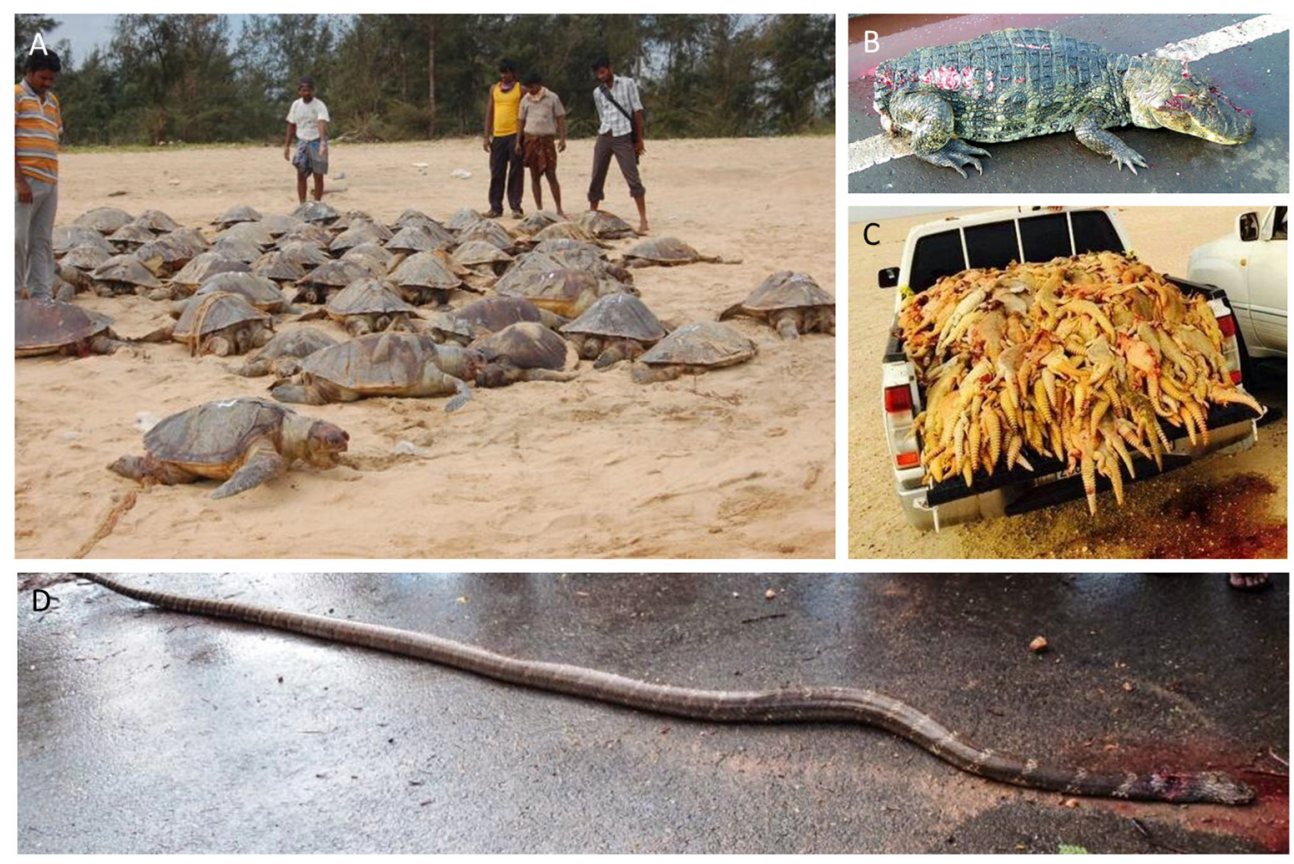

FIGURE 2 | Examples of reptiles' roles imperiled by human activities: (A) By-catch events drown up to 9,000 olive ridley turtles per year in Odisha, India (Behera et al., 2016) - sea turtles provide important surfaces for encrusting epibionts (Bjorndal and Jackson, 2003; Photo: Supraja Dharini). Crocodilians are important nutrient linkers (Nell and Frederick, 2015), and (B) shows a broad-snouted caiman (Caiman latirostris) with tail amputed while it was alive (Photo: Andrei Jara). Ecosystem engineers such as spiny tailed lizards (Uromastyx aegyptia) create burrows that offer refuge to other species in their native desert landscapes (Williams et al., 1999); they are, however, are hunted in their hundreds for meat, as seen in (C) (Anonymous photo). Reptiles can be important predators, yet, they are widely feared (Shankar et al., 2013); (D) shows the snake-eating king cobra (Ophiophagus hanna), killed by local villagers in India (Photo: Eastern Ghats Wildlife Society). 
ecosystems. Given their restricted distributions and vulnerability to introduced species, insular lizards are a highly threatened taxa (Olesen and Valido, 2003). The largest skink on Earth, Chioninia coctei, went extinct after European colonization of Cabo Verde (Vasconcelos et al., 2013). Several other extinctions have occurred between pollinating lizards, including gecko pollinators as Phelsuma edwardnewtoni and P. gigas in the Mascarene archipelago (Hansen et al., 2006).

When the area for colonization is limited, the encrustation of other animals may become a viable strategy for sessile and sedentary marine animals. Reptiles generally have a hard tegument and can consequently act as habitat for epibionts-organisms that live on the surface of others. Barnacles (infraclass Cirripedia) are found on all species of marine turtles (Hayashi, 2012). As a result, sea turtles are known to play key roles in barnacle phylogeography (Pinou et al., 2013).

Crocodilians that inhabit brackish waters can also play host to barnacles and epibionts, and these have been found on Crocodylus porosus (Monroe and Garrett, 1979), Crocodylus acutus (Cupul-Magaña, 2011), and subtropical species as Alligator mississippiensis (Nifong and Frick, 2011). Barnacles have also been found on unexpected hosts such as brackish water turtles (Arndt, 1975; Seigel, 1983; Cedillo-Leal et al., 2013), and marine snakes, which are associated with 48 barnacle species (Pfaller et al., 2012).

In sea turtles, barnacles are only one of the many associated epibionts, and more than 200 species have been found on a single turtle species (Frick et al., 2004). A known epibiont of sea turtles are remoras (Echeneidae), which have been recorded associating with all sea turtles (Lazo-Wasem et al., 2011). Sessile forms include algae, bryozoans, cnidarians, foraminiferans, mollusks, poriferans, and tunicates. Sedentary species include amphipods, polychaete worms, and tanaids. The minitature reef produced by sessile and sedentary epibiota creates conditions for colonization by motile organisms such as annelid worms, copepods, echinoderms, decapods, dipterans, ostracods, platyhelminth worms, protozoans, sipunculid worms, and peracarids, which sometimes results in the formation of an ecosystem on the turtle hard integument (Frick et al., 2004).

Organism movement by reptiles is likely to have several benefits for the associating species: (a) seed survival is greater away from the parent plant (Fricke et al., 2013); (b) pollination enhances the volume, speed, and synchrony of fertilization (Kormann et al., 2016); (c) epibiosis allows species that attach to reach specific sites that are favorable for survival, such as nutrient- or prey-rich microhabitats (Hayashi and Tsuji, 2007). Finally, at larger scale, these movements may allow associated organisms to colonize vacant habitats and, or, new regions. However, many of the reptiles performing gene transport roles in tropical regions are threatened with extinction (Figure 2A) or are already extinct-with severe knowledge gaps on role of gene dispersal at Table $\mathbf{1}$.

\section{Reptiles as Nutrient Transporters}

Large animals disproportionately drive lateral nutrient movement, and their widespread demise is disrupting the processes that result in the efficient distribution of nutrients from the oceans on to dry land (Doughty et al., 2015), as in aquatic turtles that lay on land. While biogeochemical cycles determine the limits of nutrient flows from terrestrial to aquatic ecosystems, the movements of these organisms can partially reverse this trend (Helfield and Naiman, 2001). Large reptiles can act as nutrient transporters in two main ways: (a) through reproduction, when aquatic reptiles lay eggs in terrestrial environments (Bouchard and Bjorndal, 2000), and (b) through predation, when aquatic reptiles are killed and dragged onto land by terrestrial predators (Veríssimo et al., 2012). Due to reproduction being a risky phase of aquatic reptile life history, during which predation is common, those processes are not necessarily separate.

TABLE 1 | Examples of large tropical reptiles as gene transporters.

\begin{tabular}{|c|c|c|c|}
\hline $\begin{array}{l}\text { Ecological } \\
\text { service }\end{array}$ & Providers sample & $\begin{array}{l}\text { Potential } \\
\text { measured? }\end{array}$ & $\begin{array}{l}\text { Extinct providers } \\
\text { sample* }\end{array}$ \\
\hline \multicolumn{4}{|c|}{ SEED DISPERSERS } \\
\hline Neotropical & $\begin{array}{l}\text { Podocnemis } \\
\text { expansa }{ }^{1} \\
\text { Nine Cyclura species }{ }^{2}\end{array}$ & No & $\begin{array}{l}\text { Chelonoidis alburyorum } \\
\text { C. cubensis } \\
\text { Five other undescribed } \\
\text { species }\end{array}$ \\
\hline Afrotropical & $\begin{array}{l}\text { Centrochelys sulcata } \\
\text { Kinixys erosa }\end{array}$ & No & $\begin{array}{l}\text { Aldabrachelys } \\
\text { grandidieri } \\
\text { A. abrupta } \\
\text { Centrochelys robusta }\end{array}$ \\
\hline Indomalayan & $\begin{array}{l}\text { Manouria emys }{ }^{5} \\
\text { Six Batagur species } 6\end{array}$ & No & Megalochelys species \\
\hline Oceania & None living ${ }^{\star}$ & No & $\begin{array}{l}\text { Four Meiolania species } \\
\text { Brachylophus gibbonsi } \\
\text { Lapitiguana impensa }\end{array}$ \\
\hline \multicolumn{4}{|c|}{ POLLINATORS } \\
\hline Atlantic & $\begin{array}{l}\text { Euprepis atlanticus }{ }^{7} \\
\text { Teira dugesii }\end{array}$ & No & None \\
\hline Pacific & $\begin{array}{l}\text { Microlophus species } \\
\text { Rhacodactylus } \\
\text { auriculatus }^{10}\end{array}$ & No & None \\
\hline Indian & Phelsuma ornata ${ }^{11}$ & No & $\begin{array}{l}\text { Phelsuma } \\
\text { edwardnewtoni } \\
\text { P. gigas }\end{array}$ \\
\hline \multicolumn{4}{|c|}{ SUBSTRATA FOR EPIBIONTS } \\
\hline Atlantic & $\begin{array}{l}\text { All marine turtles } \\
\text { Alligator }^{12} \\
\text { mississippiensis }^{13} \\
\text { Crocodylus acutus }^{14} \\
\text { Trachemys venusta }^{15} \\
\text { Pseudemys } \\
\text { rubriventris }^{16} \\
\text { Malaclemys terrapin }^{17}\end{array}$ & Yes & None \\
\hline Pacific & All marine turtles ${ }^{12}$ & No & None \\
\hline Indian & $\begin{array}{l}\text { All marine turtles } \\
\text { Crocodylus porosus }^{18}\end{array}$ & No & None \\
\hline
\end{tabular}

*Presumed role inferred by habits of extant species. ${ }^{1}$ Kubitzki and Ziburski (1994); ${ }^{2}$ Auffenberg (1982); ${ }^{3}$ Hansen et al. (2010); ${ }^{4}$ Hailey et al. (1998); ${ }^{5}$ Lambert and Howes (1994); ${ }^{6}$ Holloway (2003); ${ }^{7}$ Sazima et al. (2005); ${ }^{8}$ Olesen and Valido (2003); ${ }^{9}$ Chamorro et al. (2012); ${ }^{10}$ Hopkins et al. (2015); ${ }^{11}$ Hansen et al. (2006); ${ }^{12}$ Bjorndal and Jackson (2003); ${ }^{13}$ Nifong and Frick (2011); ${ }^{14}$ Cupul-Magaña (2011); ${ }^{15}$ Cedillo-Leal et al. (2013); ${ }^{16}$ Arndt (1975); ${ }^{17}$ Seigel (1983); ${ }^{18}$ Monroe and Garrett (1979). 
Reproduction-based nutrient transport can be demonstrated in the worldwide phenomena of turtles nesting on sandy beaches (Bouchard and Bjorndal, 2000). These annual events result in the terrestrial transfer of enormous volumes of nutrients originally gathered by turtles on aquatic feeding grounds. For example, the Mexican Pacific population of the olive ridley turtle was estimated to consist of $\sim 10$ million individuals (Spotila, 2004), of which some 5 million were likely to be adult females averaging $35 \mathrm{~kg}$ (Miller, 1997). Olive ridley turtles breed annually, laying 1-3 clutches averaging $2.8 \mathrm{~kg}$ (Elgar and Heaphy, 1989). This would result in the annual transfer of 14,000-42,000 tons of egg-based material on to land, a considerable entry of nutrients for an oligotrophic sand beach. Similarly, in freshwater beaches of Amazonia (Figure 1D), more than 6,000 giant river turtles, each weighing around $35 \mathrm{~kg}$, offer an input of more than 16 tons of eggs on a single beach each year (Alho and Pádua, 1982). Considering just the Brazilian population monitored in a subsample of 120 nesting beaches (Cantarelli et al., 2014), would give a total of nearly 2,000 tons of eggs. However, these figures are for only one species and one set of beaches. When the other six Podocnemididae species of river turtle in Amazonia are also considered, and the other countries and beaches in which the species also nest, the annual volume of nutrient transfer represented by deposited eggs may be relevant to nutrient cycling in the amazon basin. A $~ 50 \%$ emergence rate (Hernández and Espinosa-Blanco, 2010; Brost et al., 2015), indicates that half of these nutrients will remain to enter terrestrial food chains in both fresh and saltwater ecotones. Nutrients can also directly enter into the terrestrial food chains through plant root absorption in both fresh and saltwater (Stegmann et al., 1988; Hannan et al., 2007); not to mention the egg shells that are slowly absorbed. If these figures are amplified to include multiple sea and freshwater turtle species nesting in multiple beaches around the globe, and we have a nutrient transport phenomenon of global scale and impact that may parallel or surpass the much-celebrated salmonderived nitrogen-transport system (Helfield and Naiman, 2001).

Since aquatic turtles, most lizards and crocodilians need to lay their eggs on land, this is far from being a uniquely South American phenomenon. In Africa, several large aquatic reptile species, including Nile giant softshell turtles (Trionyx triunguis, up to $100 \mathrm{~kg}$; Keller, 2005) and Nile crocodiles (Crocodylus niloticus, averaging $44 \mathrm{~kg} ;$ Hutton, 1987) are abundant, widespread and nest on sandy beaches. Meanwhile, in tropical Asia, sandy beach-nesting species include giant softshell turtles of the genera Chitra and Pelochelys (which can reach up to $120 \mathrm{~kg}$; Bonin et al., 2006), batagur river turtles, gharials (Gavialis gangeticus, averaging $31 \mathrm{~kg}$; Whitaker and Basu, 1982) and mugger crocodiles (Crocodylus palustris, averaging $65 \mathrm{~kg}$; Bayani et al., 2011). Although the nests of these species have the potential to transport the embodied nutrients into terrestrial ecosystems, this widespread phenomenon has been little-addressed. With the exception of Nile and mugger crocodiles, all of these sand-nesters are now extirpated throughout most of their ranges, and are all considered under risk (Stevenson and Whitaker, 2010; Rhodin et al., 2011).

Predators can consume aquatic reptiles on a large scale. Jaguars (Panthera onca) are the largest felids in the Neotropics, and crocodilians can represent more than $70 \%$ of its prey (Da Silveira et al., 2010). Caimans are consistently killed by jaguars in Neotropical floodplain habitats as the Pantanal (Azevedo and Verdade, 2012), Amazon (Emmons, 1987), and Llanos (Scognamillo et al., 2003). In Central America jaguar prey on nesting sea turtles. Such nesting events can attract jaguars to the beach in their dozens, and modify their ranging behavior (Carrillo et al., 2009; Guilder et al., 2015). So extensive is the predation that, at some sites, sea turtles can comprise up to a third of the total annual jaguar diet (Chinchilla, 1997). This was probably a widespread behavior before human colonization eliminated the majority of both coastal jaguar populations, and sea turtle nesting areas.

Once killed by predators, aquatic reptiles are often dragged for hundreds of meters inland (Carrillo et al., 2009; Azevedo and Verdade, 2012) where the uneaten remnants of their carcasses will decay, releasing nutrients in terrestrial ecosystems. As in other cases, this phenomenon is not restricted to South America. In the Sundarbans mangrove of India, tigers prey on water monitors (Varanus salvadorii) that represent as much as $12 \%$ of their diet (Mukherjee and Sarkar, 2013). In Africa, fish eagles (Haliaeetus vocifer) and crowned eagles (Stephanoaetus coronatus) are known to prey on the semiaquatic Nile monitor (Boshoff and Palmer, 1994; Stewart et al., 1997), which in turn is a predator of crocodile nests and juveniles (Kofron, 1989). African fish eagles also prey directly on young Nile crocodiles (Cott, 1961). In Australia, water goannas (Varanus mertensi) are prey for dingoes (Canis lupus dingo; Sutherland et al., 2011), while both varanids and dingoes are frequent predators of crocodile eggs (Somaweera et al., 2011).

With high standing crop and large body size, reptiles may have a strong positive impact on nutrient flow from aquatic to terrestrial tropical ecosystems. As consumers of aquatic organisms and as prey for terrestrial predators, they can act as important nutrient vectors. While some species may still be highly abundant in some areas (Campos and Magnusson, 2016), numerous populations are in severe decline (Thorbjarnarson, 1999; Rhodin et al., 2011). In fact population sizes of both turtles and crocodilians are now well below the historical levels witnessed by the first naturalists on scientific expeditions (e.g., Von Humboldt, 1877), suggesting that for many species (Figure 2B), current numbers are a mere relic of their former abundance. In Table 2, further examples of threatened reptiles providing nutrient movement-as well as current gaps on knowledge-can be seen.

\section{Reptiles as Trophic Actors}

Reptiles can act as top predators in aquatic and terrestrial ecosystems. Crocodilians are conspicuously present as predators in aquatic-terrestrial interfaces in the tropical regions of all continents. Like other predators, crocodilians can exert top-down pressure on prey species populations (Nifong and Silliman, 2013). Such interactions have the potential to regulate prey populations, as well as modulate their access to key resources, such as water (Doody et al., 2007). Opposed to the opinions of those who study mammalian carnivores, crocodilians are the largest predators in tropical regions on all continents. Indeed, within a given area, 
TABLE 2 | Examples of large tropical reptiles as nutrient linkers.

\begin{tabular}{|c|c|c|c|}
\hline $\begin{array}{l}\text { Ecological } \\
\text { service }\end{array}$ & Providers sample & $\begin{array}{l}\text { Potential scale } \\
\text { measured? }\end{array}$ & Extinct providers* \\
\hline \multicolumn{4}{|c|}{ MARINE TO TERRESTRIAL ${ }^{1}$} \\
\hline Pacific & $\begin{array}{l}\text { Chelonia mydas } \\
\text { Caretta caretta } \\
\text { Lepidochelys olivacea } \\
\text { Eretmochelys } \\
\text { imbricata } \\
\text { Dermochelys coriacea }\end{array}$ & No & None \\
\hline Atlantic & $\begin{array}{l}\text { Chelonia mydas } \\
\text { Caretta caretta } \\
\text { Lepidochelys species } \\
\text { Eretmochelys } \\
\text { imbricata } \\
\text { Dermochelys coriacea }\end{array}$ & Yes & None \\
\hline Indian & $\begin{array}{l}\text { Chelonia mydas } \\
\text { Caretta caretta } \\
\text { Lepidochelys olivacea } \\
\text { Eretmochelys } \\
\text { imbricata } \\
\text { Natator depressus } \\
\text { Dermochelys coriacea }\end{array}$ & No & None \\
\hline \multicolumn{4}{|c|}{ RIVER TO TERRESTRIAL2, 3} \\
\hline Neotropical & $\begin{array}{l}\text { Podocnemis expansa } \\
\text { Caiman latirostris }\end{array}$ & No & None \\
\hline Afrotropical & $\begin{array}{l}\text { Crodylus niloticus } \\
\text { Trionyx triunguis }\end{array}$ & No & Voay robustus \\
\hline Indomalayan & $\begin{array}{l}\text { Six Batagur species } \\
\text { All softshell turtles } \\
\text { Crocodylus palustris }\end{array}$ & No & None \\
\hline Oceania & $\begin{array}{l}\text { Carettochelys } \\
\text { insculpta } \\
\text { Crocodylus johnstonii }\end{array}$ & No & None \\
\hline \multicolumn{4}{|c|}{ WETLANDS TO TERRESTRIAL 2,4} \\
\hline Neotropical & $\begin{array}{l}\text { Caiman yacare } \\
\text { Podocnemis vogli } \\
\text { Melanosuhus niger }\end{array}$ & No & None \\
\hline Afrotropical & $\begin{array}{l}\text { Crocodylus niloticus } \\
\text { Varanus niloticus }\end{array}$ & No & Voay robustus \\
\hline Indomalayan & $\begin{array}{l}\text { Alligator sinensis } \\
\text { Crocodylus porosus } \\
\text { Varanus salvator }\end{array}$ & No & Gavialis bengawanicus \\
\hline Oceania & $\begin{array}{l}\text { Crocodylus porosus } \\
\text { Varanus mertensi }\end{array}$ & No & Pallimnarchus pollens \\
\hline
\end{tabular}

*Presumed role inferred by habits of extant species. ${ }^{1}$ Hannan et al. (2007); ${ }^{2}$ Vitt and Caldwell (2013); ${ }^{3}$ Campos et al. (2016); ${ }^{4}$ Torralvo et al. (2017).

pythons and crocodilians can surpass mammalian carnivores both in numbers and biomass by several orders of magnitude (Campos and Magnusson, 2016; Natusch et al., 2016).

Squamate reptiles, like snakes, are capable of overpowering bird and mammalian prey (Figure 1B). They are also capable of strongly impacting avian prey populations (Patten and Bolger, 2003), and intense declines have been recorded where exotic snakes species have been introduced, as, for instance, on the island of Guam (Richmond et al., 2014). One could argue that prey suppression occurred because Guam is an insular ecosystem with prey communities in delicate equilibrium. However, the same pattern of decline is seen in species preyed upon by introduced pythons in Florida's Everglades. Unlike Guam, the Everglades is a functionally diverse continental mammal community composed of large and medium-sized species where prey declines have been shown by correlational and experimental methods (Dorcas et al., 2012; McCleery et al., 2015).

Gigantism in reptiles is commonly considered an island phenomenon, a by-product of competition-release; the Komodo dragons (Varanus komodoensis) being a frequently cited example. Since body size is such an important factor in species interactiveness, this misconception must be addressed: (i) several living giant snake species such as anacondas and pythons (e.g., Eunectes notaeus, E. murinus, Python molurus, $P$. reticulatus, $P$. sebae) occur in mainland environments, where they successfully compete with mammalian carnivores; (ii) Komodo dragons were formerly widespread over Sahul (Hocknull et al., 2009), where they competed with Thylacoleo carnifex, an extinct $100 \mathrm{~kg}$-plus marsupial carnivore (Wroe et al., 1999), so that their current distribution is a misleading relict; (iii) other species of large lizards occur on mainland Asia, such as the water monitor, a species that exceeds $20 \mathrm{~kg}$, which is smaller than only two of southeast Asia's largest mammalian predators, the tiger (Panthera tigris, $227 \mathrm{~kg}$ ) and the leopard (Panthera pardus, $42 \mathrm{~kg}$; Corlett, 2011); (iv) in the early Pleistocene, southeast Asia had giant species of monitors like Varanus sivalensis that coexisted with carnivore faunas similar to current ones (Hocknull et al., 2009). Despite this, reptiles are often completely ignored as predators in both present (Jorge and Galetti, 2013), and past ecological communities (Malhia et al., 2016). As suggested from this brief list, the popular notion of food chain apices occupied solely by mammalian carnivores must be reassessed in tropical ecosystems.

Insular giant tortoises are another example of a popular misconception regarding reptile body size: rather than being a byproduct of competition release, they evolved from continental species that were already large (Braithwaite et al., 1973; Pritchard, 1996). For instance, the largest tortoise ever, Megalochelys atlas, was an early Pleistocene continental species, which disappeared from mainland Asia and its nearest islands after the arrival of Homo erectus (Hirayama et al., 2015). An entire genus of extinct continental tortoises (Hesperotestudo spp.) contained around a dozen species that all surpassed $100 \mathrm{~cm}$ in length. The genus was exterminated in Central and North America following human colonization in the Pleistocene (Rhodin et al., 2015). In addition, it is worth noting that current large-sized continental species like the african spurred tortoise and the asian forest tortoise are likely to have reduced in size, as a result of a long history of exploitation (Lomolino et al., 2001).

Chelonians, popularly regarded as slow moving animals, can also act as top predators in aquatic ecosystems. The alligator snapping Turtles (Macrochelys species, $21 \mathrm{~kg}$ ), snapping turtle (Chelydra serpentina, $6.2 \mathrm{~kg}$ ), and several Asiatic giant softshell turtles (Rafetus swinhoei, Chitra indica, C. chitra, Pelochelys cantorii, up to $200 \mathrm{~kg}$ ), can be top consumers of fish, birds and mammals in aquatic environments, and themselves have no predators once they have reached adult size (Steyermark et al., 2008; Corlett, 2011).

As predators, reptiles can also provoke the same types of human-wildlife conflict as large mammalian carnivores. Small and large livestock species are common prey for reticulated 
pythons in Southeast Asia (Shine et al., 1998), and for anacondas in South America (Miranda et al., 2016), while cattle, buffalo and sheep fall prey to the Burmese python in Pakistan and India (Goursi et al., 2012; Bhupathy et al., 2014). Crocodiles are also known to take a toll on livestock in both Asia and Africa (Butler, 2000; Bhatnagar and Mahur, 2010). Since reptiles do not possess the same charisma as large carnivores (Bonnet et al., 2002), this research theme and conservation issue is substantially under-explored (Figure 2D).

Reptiles can act as scavengers. Varanids in Australia, Asia, and Africa are consumers of carrion (Shine and Harlow, 1998; Dalhuijsen et al., 2015), removing flesh from carcasses before they spread disease and increasing the flux of energy in trophic cascades. The Nile crocodile plays this role when scavenging the carcasses of the hundreds of ungulates that die crossing large rivers during annual migrations, through which they may reduce the spread of disease and increase water quality (Subalusky et al., 2017). While ornithologists have quantified the scale of carcass cleaning service by vultures (Pain et al., 2003), similar knowledge of carrion use by reptiles is scant. This is an interesting research gap as well as conservation issue.

As with other processes described here, the action of reptiles as trophic actors has been severely reduced by extinctions and extirpations. Several species of crocodilians, for example, are already lost. The human expansion during the late PleistoceneHolocene wiped out the last clade of terrestrial crocodiles (Mekosuchinae). They disappeared sequentially in Sahul (Sobbe et al., 2013), New Caledonia (Mead et al., 2009), Vanuatu (Mead et al., 2009), and Fiji (Irwin et al., 2011) with dates that corresponded to human arrival on each of these islands, around 53 and 3 thousand years ago in Australia and elsewhere, respectively (Roberts et al., 1994; Worthy et al., 1999; Stevenson et al., 2001; Kinaston et al., 2014). Although Sahul had a terrestrial predator fauna with large carnivorous mammals and reptiles, on smaller islands terrestrial mekosuchines were the top predators. In addition, humans caused the extinction of the Malagasy horned crocodile (Voay robustus) in the Holocene (Brochu, 2007), and the dramatic range contraction of the (now) Cuban crocodile (Crocodylus rhombifer), which occurred after human colonization of the Caribbean islands (Steadman et al., 2015). Together, these form part of the series of lost top predator roles played by reptiles. The unique ecological roles filled by Crocodilians continue under threat, with nine of the surviving 25 modern species considered to be threatened with extinction, seven of which are recognized as "Critically Endangered" under the IUCN categorizations.

Squamate reptiles, although capable of sustaining high cropping rates (Natusch et al., 2016), have also lost several species. Besides the widespread extirpation of the relictly insular Komodo dragon, the largest lizard species (Varanus priscus, averaging $320 \mathrm{~kg}$ and toping $7 \mathrm{~m}$ in length; Molnar, 2004) was eliminated in Sahul during human colonization (Flannery, 2002). Anthropogenic extinctions of giant snakes are also known. The last species of the Matsoiid snake family, Wonambi naracoortensis-a species reaching five meters long-and two other large species, W. barriei and Yurlunggur camfieldensis, also became extinct following aboriginal colonization (Flannery, 2002). Finally, the current status of some giant carnivorous turtles is far from good (Rhodin et al., 2011); hopes for the survival of the largest of their kind, $R$. swinhoei, is currently dependent on the last captive pair. Several other examples of top consumers roles performed by extinct and extant reptiles and the deart of knowledge on them can be seen in Table 3 .

\section{Reptiles as Ecosystem Engineers}

An ecosystem engineer is any organism that creates or significantly modifies habitat structure, and as a result is important for maintaining the biodiversity of the environment in which it lives (Samson and Knopf, 1996). Some herbivorous reptiles can have a profound effect on vegetation. The grazing and browsing impact of large tortoises, for example, can intensely impact vegetation composition and structure (Hamann, 1993). Giant tortoises on oceanic islands can have a great impact on their environments and exert top-down pressure, and have been described as ecosystem engineers (Gibbs et al., 2010). Considering that giant tortoises were-and in some places areconspicuous elements of continental faunas the possible impacts of their loss must be assessed.

A similar relationship of habitat engineering is known from marine ecosystems. The seagrass (Thalassia testudinum) is heavily grazed by the green turtle (Chelonia mydas). As a result, the seagrass productivity and composition is positively affected by grazing (Moran and Bjorndal, 2005). In a similar way, the hawksbill turtle has a role as a sponge predator, with preference for overabundant aggressive sponges such as Chondrilla nucula. The predation by Hawksbill Turtles affects reef diversity and succession by influencing space competition (Bjorndal and Jackson, 2003). As the Green and Hawksbill turtles are severely overexploited, their regulatory impact on marine ecosystems has been much reduced.

Another means by which reptiles can act as ecosystem engineers is via their burrows, which can provide shelter for other species. Burrowing reptiles are recognized in several dry environments (Kinlaw, 1999), and their burrows are used by a wide diversity of animals: over 300 species have been recorded using those of the gopher tortoise (Gopherus polyphemus, Kinlaw and Grasmueck, 2012), including burrowing owls (Athene cunicularia), eastern diamondback rattlesnakes (Crotalus adamanteus) and marsh rabbits (Sylvilagus palustris). While the gopher tortoise is the best-studied burrow-providing reptile, ecosystem engineering through burrows can potentially occur in several other species, including the burrowers bolson tortoises (Gopherus flavomarginatus), Mohave desert tortoises (G. agassizii) and Sonoran desert tortoises (G. morafkai) in North America and red-footed tortoises in South America. Spurred tortoises in Africa can dig burrows that are both extensive and complex, but whose effects on other species are still unknown (Kinlaw and Grasmueck, 2012). Spurred tortoise burrows have great ecosystem engineering potential, as they are huge, up to $15 \mathrm{~m}$ long (Devaux, 2000) and occur in Sahel semidesert landscapes, where cover is otherwise scarce. Ecosystem engineering also occurs with smaller reptilian species: $<1 \mathrm{~kg}$ spiny tailed lizards dig burrows in coverless arid environments and have been shown to be ecosystem engineers by providing shelter to a variety of other organisms (Wilms et al., 2010). 
TABLE 3 | Examples of reptiles as trophic agents.

\begin{tabular}{lll}
\hline $\begin{array}{l}\text { Ecological } \\
\text { service }\end{array}$ & Providers sample & $\begin{array}{l}\text { Potential scale Extinct providers* } \\
\text { measured? }\end{array}$
\end{tabular}

\begin{tabular}{|c|c|c|c|}
\hline \multicolumn{4}{|c|}{ GRAZING, BROWSING, AND TRAMPLING } \\
\hline Neotropical ${ }^{1,2}$ & $\begin{array}{l}\text { Chelonoidis species } \\
\text { Iguana species } \\
\text { Nine Cyclura species }\end{array}$ & No & $\begin{array}{l}\text { Chelonoidis species } \\
\text { Hesperotestudo } \\
\text { species }\end{array}$ \\
\hline Afrotropical $^{3}$ & $\begin{array}{l}\text { Centrochelys sulcata } \\
\text { Stygmochelys pardalis }\end{array}$ & No & $\begin{array}{l}\text { Five Cylindraspis } \\
\text { species } \\
\text { Aldabrachelys species } \\
\text { Centrochelys species }\end{array}$ \\
\hline Indomalayan ${ }^{4}$ & $\begin{array}{l}\text { Manouria emys } \\
\text { Manouria impressa }\end{array}$ & No & $\begin{array}{l}\text { Megalochelys species } \\
\text { Manouria punjabiensis }\end{array}$ \\
\hline Oceania & None alive & No & $\begin{array}{l}\text { Four Meiolania species } \\
\text { Brachylophus gibbonsi } \\
\text { Lapitiguana impensa }\end{array}$ \\
\hline
\end{tabular}

TOP PREDATORS

\begin{tabular}{|c|c|c|c|}
\hline Neotropical ${ }^{5}$ & $\begin{array}{l}\text { Eunectes murinus } \\
\text { Melanosuchus niger } \\
\text { Crocodylus rhombifer }\end{array}$ & No & None \\
\hline Afrotropical ${ }^{6}$ & $\begin{array}{l}\text { Crocodylus niloticus } \\
\text { Python sebae } \\
\text { Tronyx triunguis }\end{array}$ & No & Voay robustus \\
\hline Indomalayan ${ }^{7}$ & $\begin{array}{l}\text { Crocodylus porosus } \\
\text { Python reticulatus } \\
\text { Chitra chitra }\end{array}$ & No & $\begin{array}{l}\text { Gavialis bengawanicus } \\
\text { Rafetus swinhoei }\end{array}$ \\
\hline Oceania $^{8}$ & $\begin{array}{l}\text { Crocodylus porosus } \\
\text { Varanus giganteus }\end{array}$ & No & $\begin{array}{l}\text { Varanus priscus } \\
\text { Mekosuchus species } \\
\text { Volia athollandersoni }\end{array}$ \\
\hline \multicolumn{4}{|c|}{ SCAVENGERS } \\
\hline Neotropical $^{9}$ & $\begin{array}{l}\text { Tupinambis lizards } \\
\text { Crocodylus } \\
\text { intermedius }\end{array}$ & No & None \\
\hline Afrotropical $^{6}$ & $\begin{array}{l}\text { Crocodylus niloticus } \\
\text { Varanus niloticus }\end{array}$ & No & Voay robustus \\
\hline Indomalayan ${ }^{10}$ & $\begin{array}{l}\text { Varanus salvator } \\
\text { Crocodylus palustris }\end{array}$ & No & None \\
\hline Oceania $^{11}$ & $\begin{array}{l}\text { Crocodilus porosus } \\
\text { Varanus gouldii }\end{array}$ & No & $\begin{array}{l}\text { Varanus priscus } \\
\text { Mekosuchus species } \\
\text { Volia athollandersoni }\end{array}$ \\
\hline
\end{tabular}

${ }^{*}$ Presumed role inferred by habits of extant species. ${ }^{1}$ Froyd et al. (2014); ${ }^{2}$ Rodda et al. (2001); ${ }^{3}$ Burney et al. (2012); ${ }^{4}$ Lambert and Howes (1994); ${ }^{5}$ Cavalcanti et al. (2016); ${ }^{6}$ Ashton (2010); ${ }^{7}$ Fredriksson (2005); ${ }^{8}$ Hanson et al. (2015); ${ }^{9}$ Sazima and D'Angelo (2013); ${ }^{10}$ Shine et al. (1996); ${ }^{11}$ Doody (2009).

Crocodilians can act as providers of shelter, digging extensive burrow systems in those areas of Asia, Africa, and North America where avoiding seasonal harshness requires aestivation (Whitaker et al., 2007; Brito et al., 2011). While such burrows may include galleries several meters deep, their use by other species is little known. During the dry season in the Everglades, wallow holes created by alligators (Figure 1A) act as a refuge for several species of fishes, birds, and aquatic reptiles, providing areas of deeper water that sustain populations until they can colonize more extensive water bodies at the onset of the next high water season (Palmer and Mazzotti, 2004).

Another way in which crocodilians can act as ecosystem engineers is via the mounds of rotting vegetation they assemble for egg laying. The subtropical american alligator nest mounds are used by other reptiles as nesting habitats. They include eight turtle species, two snakes and two lizards, which all lay their eggs in alligator mounds (Deitz and Hines, 1980; Kushlan and Kushlan, 1980; Elsey et al., 2013). While some species do this facultatively, the Florida red-bellied turtle (Chrysemys rubriventris) is a specialist mound-nester, and a single alligator nest mound may hold up to 200 of their eggs (Deitz and Hines, 1980). This phenomena is mirrored by amazonian yellowspotted river turtles (Podocnemis unifilis), which sometimes nest in black caiman (Melanosuchus niger) mounds (Maffei and Da Silveira, 2013), and by basilisks (Basiliscus vittatus) and red-eared sliders (Trachemys scripta) which lay eggs in the nest mounds of Morelet's crocodile (Crocodylus moreletii; Platt et al., 2008). The apparent reduced richness of commensals in the nests of species other than alligators may be related to the fact that alligators are the best studied crocodilian species, suggesting that the subject merits further research in other crocodilians.

Several species with potential to act as ecosystems engineer are now threatened or extinct and severe knowledge gaps remains (Table 4). Do the mounds and holes of the chinese alligator (Alligator sinensis) have similar effects on the aquatic communities in the Yangtze River Basin? We may never know, because these $1.5 \mathrm{~m}, 36 \mathrm{~kg}$ animals are functionally extinct in the wild (Ding et al., 2001). This fate is yet another to be added to the long list of vanished or functionally extinct reptiles already cited in this text, that continues to grow every year (Turvey et al., 2017).

\section{HOW CAN WE REDRESS THIS BIAS IN CONSERVATION AND RESEARCH EFFORTS?}

In this review I have shown that reptiles in tropical environments can be large and abundant animals, which consequently have the potential to regulate several important ecosystem processes. But since Homo sapiens species' dispersion during the Pleistocene-Holocene, many of the larger-and thus most ecosystem-interactive-reptile species have become extinct. The continuation of this process has caused extinction and extirpation of many large modern reptiles, while others are extinct in the wild or now functionally absent.

In tropical ecosystems reptiles can achieve standing biomasses that equal or surpass that of any other air-breathing vertebrate (Campos and Magnusson, 2016; Natusch et al., 2016). We can only wonder how abundant they were before humanity's extraordinary capacity as a predator (Darimont et al., 2015) overexploited these populations, in many cases terminally. While reptiles can attain high standing biomasses, population growth is low-particularly for the large-sized, k-selected species covered here (Ferreira and Pienaar, 2011). They are also subject to progressive dwarfism induced by hunting (Lomolino et al., 2001), and many of the species we now consider large may have been bigger in the past. Despite this, reptiles are still widely ignored as megafauna.

Extinctions and extirpations imperil or severely reduce many of the processes that I have described (Figure 2). Because 
TABLE 4 | Examples of reptiles as ecosystem engineers.

\begin{tabular}{|c|c|c|c|}
\hline $\begin{array}{l}\text { Ecological } \\
\text { service }\end{array}$ & Providers sample & $\begin{array}{l}\text { Potential scale } \\
\text { measured? }\end{array}$ & Extinct providers* \\
\hline \multicolumn{4}{|l|}{ BURROWERS } \\
\hline Neotropical $^{1}$ & $\begin{array}{l}\text { Chelonoidis } \\
\text { denticulatus } \\
\text { Tupinambis species } \\
\text { Six Gopherus species }\end{array}$ & No & $\begin{array}{l}\text { Hesperotestudo } \\
\text { species }\end{array}$ \\
\hline Afrotropical $^{2}$ & $\begin{array}{l}\text { Centrochelys sulcata } \\
\text { Crocodylus niloticus } \\
\text { Several Uromastyx } \\
\text { species }\end{array}$ & No & $\begin{array}{l}\text { Insular Centrochelys } \\
\text { species }\end{array}$ \\
\hline Indomalayan ${ }^{3}$ & $\begin{array}{l}\text { Varanus bengalensis } \\
\text { Crocodilus palustris }\end{array}$ & No & None know \\
\hline Oceania $^{4}$ & $\begin{array}{l}\text { Several Varanus } \\
\text { species }\end{array}$ & No & Varanus priscus \\
\hline \multicolumn{4}{|c|}{ NESTING HABITAT } \\
\hline Neotropical $^{5}$ & $\begin{array}{l}\text { Alligator } \\
\text { mississipiensis }\end{array}$ & Yes & None know \\
\hline Afrotropical ${ }^{6}$ & Osteolaemus species & No & None know \\
\hline Indomalayan 6 & Manouria emys & No & None know \\
\hline Oceania $^{6}$ & Crocodylus porosus & No & None know \\
\hline \multicolumn{4}{|c|}{ POOL MAKERS } \\
\hline Neotropical $^{7,8}$ & $\begin{array}{l}\text { Alligator } \\
\text { mississipiensis } \\
\text { Chelonoidis nigra } \\
\text { complex }\end{array}$ & Yes & $\begin{array}{l}\text { Several } \\
\text { Chelonoidis nigra } \\
\text { complex species }\end{array}$ \\
\hline Afrotropical & $\begin{array}{l}\text { Cylindraspis species* } \\
\text { Aldabrachelys } \\
\text { species }^{\star}\end{array}$ & No & $\begin{array}{l}\text { Cylindraspis species } \\
\text { Aldabrachelys species }\end{array}$ \\
\hline Indomalayan & None know & No & Alligator sinensis \\
\hline Oceania & None know & No & None know \\
\hline
\end{tabular}

${ }^{*}$ Presumed role inferred by habits of extant or similar species. ${ }^{1}$ Kinlaw and Grasmueck (2012); ${ }^{2}$ Devaux (2000); ${ }^{3}$ Whitaker et al. (2007); ${ }^{4}$ King (1980); ${ }^{5}$ Kushlan and Kushlan (1980); ${ }^{6}$ these species build organic matter nests that may be shared by other species in habitats that are thermally challenging shaded forests or where dry surface is scarce; 7Palmer and Mazzotti (2004); ${ }^{8}$ Froyd et al. (2014).

reptiles are rarely as noisy as birds or conspicuous as large mammals, they often pass unnoticed as ecosystem players, even when they are plentiful. Add to this the general unpopularity of studying reptiles as performer of ecological processes, and the result, with few exceptions, is a comparative dearth of research on their ecological functions. To readdress this bias and increase awareness of longstanding demise of reptiles, and highlight their broad and important ecological functions, I recommend:

a. Increasing efforts in spreading information about Pleistocene-Holocene reptile extinctions using popular media, to inspire new scientists on the subject and also increase funding potential-as Jurassic Park did for paleonthological research (Stokstad, 1998). For building such links, large reptile researchers must work on networks with documentary, popular and rural news teams. Under such a strategy, conservation biologists and general public may become equally familiar with the existence of more recent dragon-like giants. b. "Cross-pollination" between stablished research field of megafauna effects in ecosystems and herpetologists working with large reptiles, as well as with excellent research programs running on some reptilian megafauna (e.g., Everglades pythons, Komodo dragons, sea turtles). This strategy has proven successful in other ecological research fields (Wirsing and Ripple, 2011).

c. Increasing research effort on anthropogenic reptile extinctions and their potential to predict the nature of future losses. Milestone research as recently done by Rhodin et al. (2015) and Slavenko et al. (2016) merits replication in further reptile groups and contexts.

d. Address the knowledge gaps. Human-reptile conflict is a usual problem for every city and rural landscapes on the tropics. There, anacondas, pythons and crocodilians threaten human lives and livestock, a problem that has been scantly addressed by research. Tortoise and turtles are proficuous seed dispersers and the research produced to date can be summarized in a metanalysis to identify specific gaps and conservation priorities, as has been done by Sobral-Souza et al. (2017) regarding reintroductions. Nutrient movement performed by land-nesting aquatic reptiles can be accessed by stable isotope research, replicating the results obtained in sea turtles (Bouchard and Bjorndal, 2000).

e. Increasing quantitative research on large reptile population ecology, with emphasis on density, abundance, and biomass; most threatened species lack any estimates.

f. Further research on the potentially present or lost ecosystem effects of extant and extinct reptile species. The few, but exemplary, research programs on sea turtles (Bjorndal and Jackson, 2003; Heithaus et al., 2014), should be mirrored by studies on other reptile groups and sites.

Since the charisma of a species seems to be important to humanity's willingness to engage in collective effort to preserve it (Colléony et al., 2017), reptile conservationists have a hard road ahead. Biodiversity loss in an anthropogenic age of extinctions is pressing many species groups. Let us not add to reptiles the pressure of our silence.

\section{AUTHOR CONTRIBUTIONS}

The author confirms being the sole contributor of this work and approved it for publication.

\section{FUNDING}

I thank the Conselho Nacional de Desenvolvimento Científico e Tecnológico (CNPq) for the grant 130873/2014-4 and the Sheikh MBZ Species Conservation Fund (Project 162513780) for making this work possible.

\section{ACKNOWLEDGMENTS}

I am indebted to Bernardo Araújo and Leonardo Moreira who improved a first version of this manuscript with their comments. 


\section{REFERENCES}

Acemoglu, D., and Robinson, J. (2012). Why Nations Fail: The Origins of Power, Prosperity and Poverty, 1st Edn. London: Profile Books. Available online at: http://www.scielo.cl/pdf/rei/v45n174/art09.pdf (Accessed November 15, 2015).

Alho, C. J. R., and Pádua, L. F. M. (1982). Reproductive parameters and nesting behavior of the Amazon turtle Podocnemis expansa (Testudinata: Pelomedusidae) in Brazil. Can. J. Zool. 60, 97-103. doi: 10.1139/z82-012

Alroy, J. (2015). Current extinction rates of reptiles and amphibians. Proc. Natl. Acad. Sci. U.S.A. 112, 13003-13008. doi: 10.1073/pnas.1508681112

Andriantsaralaza, S., Pedrono, M., Tassin, J., Roger, E., Rakouth, B., and Danthu, P. (2014). The role of extinct giant tortoises in the germination of extant baobab Adansonia rubrostipa seeds in Madagascar. Afr. J. Ecol. 52, 246-249. doi: 10.1111/aje.12101

Aristoff, J. M., Stocker, R., Reis, P. M., and Jung, S. (2011). On the water lapping of felines and the water running of lizards: a unifying physical perspective. Commun. Integr. Biol. 4, 213-215. doi: 10.4161/cib.4.2.14493

Arndt, R. (1975). The occurrence of barnacles and algae on the red-bellied turtle, Chrysemys r. rubriventris (Le Conte). J. Herpetol. 9, 357-359. doi: $10.2307 / 1562939$

Ashton, P. J. (2010). The demise of the Nile crocodile (Crocodylus niloticus) as a keystone species for aquatic ecosystem conservation in South Africa: the case of the Olifants River. Mar. Freshw. Ecosyst. 20, 489-493. doi: 10.1002/aqc.1132

ATTWG (2016). Batagur baska: e.T2614A97331162. IUCN Red List Threat. Species/Asian Turt. Trade Work. Gr. Available online at: http://www.iucnredlist. org/details/2614/0 (Accessed August 3, 2016).

Auffenberg, W. (1982). "Feeding strategy of the Caicos ground iguana, Cyclura carinata," in Iguanas of the World: Their Behavior, Ecology, and Conservation, eds G. M. Burghardt and A. S. Rand (Park Ridge, NJ: Society of the Study of Amphibians and Reptiles and The Herpetologist's League), 84-116.

Azevedo, F. C. C., and Murray, D. L. (2007). Spatial organization and food habits of jaguars (Panthera onca) in a floodplain forest. Biol. Conserv. 137, 391-402. doi: 10.1016/j.biocon.2007.02.022

Azevedo, F. C. C., and Verdade, L. M. (2012). Predator-prey interactions: jaguar predation on caiman in a floodplain forest. J. Zool. 286, 200-207. doi: 10.1111/j.1469-7998.2011.00867.x

Bayani, A., Trivedi, J., and Suresh, B. (2011). Nesting behaviour of Crocodylus palustris (lesson) and probable survival benefits due to the varied nest structures. Electron. J. Environ. Sci. 4, 85-90.

Behera, S., Tripathy, B., Sivakumar, K., Choudhury, B. C., and Pandav, B. (2016). Fisheries impact on breeding of olive ridley turtles (Lepidochelys olivacea) along the Gahirmatha coast, Bay of Bengal, Odisha, India 26(2). Herpetol. J. 26, 93-98.

Bell, L. (2011). Stop The Drilling! A Lizard Is Imperiled. Forbes, 1. Available online at: http://www.forbes.com/sites/larrybell/2011/05/10/stop-the-drillinga-lizard-is-imperiled/\#3fa955e23569

Benítez-Malvido, J., Tapia, E., Suazo, I., Villaseñor, E., and Alvarado, J. (2003). Germination and seed damage in tropical dry forest plants ingested by iguanas. J. Herpetol. 37, 301-308. doi: 10.1670/0022-1511(2003)037[0301:GASDIT]2.0. $\mathrm{CO} ; 2$

Bennett, D. (2014). The arboreal foraging behavior of the frugivorous monitor lizard Varanus olivaceus on Polillo Island. Biawak 8, 15-18.

Benton, M. (2014). Vertebrate Palaeontology, 4th Edn. John Wiley \& Sons.

Bhatnagar, C., and Mahur, M. (2010). Observations on feeding behavior of a wild population of marsh crocodile in Baghdarrah Lake, Udaipur, Rajasthan. Reptil. Rap. 10, 16-18.

Bhupathy, S., Ramesh, C., and Bahuguna, A. (2014). Feeding habits of Indian rock pythons in Keoladeo National Park, Bharatpur, India. Herpetol. J. 24, 59-64.

Bjorndal, K. A., and Jackson, J. B. C. (2003). "Roles of sea turtles in marine ecosystems: reconstructing the past," in The Biology of Sea Turtles, eds P. L. Lutz, J. A. Musick, and J. Wyneken (Boca Ratón, FL: CRC Press), 259-273.

Blake, S., Wikelski, M., Cabrera, F., Guezou, A., Silva, M., Sadeghayobi, E., et al. (2012). Seed dispersal by Galápagos tortoises. J. Biogeogr. 39, 1961-1972. doi: 10.1111/j.1365-2699.2011.02672.x

Böhm, M., Collen, B., Baillie, J. E. M., Bowles, P., Chanson, J., Cox, N., et al. (2013). The conservation status of the world's reptiles. Biol. Conserv. 157, 372-385. doi: 10.1016/j.biocon.2012.07.015
Bonin, F., Devaux, B., and Dupré, A. (2006). Turtles of the World. Baltimore, MD: JHU Press.

Bonnet, X., Shine, R., and Lourdais, O. (2002). Taxonomic chauvinism. Trends Ecol. Evol. 17, 1-3. doi: 10.1016/S0169-5347(01)02381-3

Boshoff, A., and Palmer, N. (1994). Comparison of the diet of crowned eagles in the savanna and forest biomes of south-eastern South Africa. S. Afr. J. Wildl. Res. 24, 26-31.

Bouchard, S. S., and Bjorndal, K. A. (2000). Sea turtle as biological transportes of nutrients and energy from marine to terrestrial ecosystems. Ecology 81, 2305-2313. doi: 10.1890/0012-9658(2000)081[2305:STABTO]2.0.CO;2

Bovendorp, R. S., Alvarez, A. D., and Galetti, M. (2008). Density of the tegu Lizard (Tupinambis merianae) and its role as nest predator at Anchieta Island, Brazil. Neotrop. Biol. Conserv. 3, 9-12. doi: 10.4013/5439

Braithwaite, C. J. R., Taylor, J. D., and Kennedy, W. J. (1973). The evolution of an atoll: the depositional and erosional history of Aldabra. Philos. Trans. R. Soc. B Biol. Sci. 266, 307-340. doi: 10.1098/rstb.1973.0051

Brito, J. C., Martínez-Freiría, F., Sierra, P., Sillero, N., and Tarroso, P. (2011). Crocodiles in the Sahara desert: an update of distribution, habitats and population status for conservation planning in Mauritania. PLoS ONE 6:e14734. doi: 10.1371/journal.pone.0014734

Brochu, C. A. (2007). Morphology, relationships, and biogeographical significance of an extinct horned crocodile (Crocodylia, Crocodylidae) from the Quaternary of Madagascar. Zool. J. Linn. Soc. 150, 835-863. doi: 10.1111/j.1096-3642.2007.00315.x

Brost, B., Witherington, B., Meylan, A., Leone, E., Ehrhart, L., and Bagley, D. (2015). Sea turtle hatchling production from Florida (USA) beaches, 2002-2012, with recommendations for analyzing hatching success. Endanger. Species Res. 27, 53-68. doi: 10.3354/esr00653

Burney, D. A., Juvik, J. O., Burney, L. P., and Diagne, T. (2012). Can Unwanted Suburban Tortoises Rescue Native Hawaiian Plants. New York, NY: Magazine: The Tortoise; The Turtle Conservancy.

Butler, J. R. A. (2000). The economic costs of wildlife predation on livestock in Gokwe communal land, Zimbabwe. Afr. J. Ecol. 38, 23-30. doi: 10.1046/j.1365-2028.2000.00209.x

Campos, Z., and Magnusson, W. E. (2016). Density and biomass estimates by removal for an amazonian crocodilian, Paleosuchus palpebrosus. PLoS ONE 11:e0156406. doi: 10.1371/journal.pone.0156406

Campos, Z., Muniz, F., Desbiez, A. J., and Magnusson, W. E. (2016). Predation on eggs of Schneider's dwarf caiman, Paleosuchus trigonatus (Schneider, 1807), by armadillos and other predators. J. Nat. Hist. 50, 1543-1548. doi: 10.1080/00222933.2016.1155782

Cantarelli, V. H., Malvasio, A., and Verdade, L. M. (2014). Brazil's Podocnemis expansa conservation program: retrospective and future directions. Chelonian Conserv. Biol. 13, 124-128. doi: 10.2744/CCB-0926.1

Carrillo, E., Fuller, T. K., and Saenz, J. C. (2009). Jaguar (Panthera onca) hunting activity: effects of prey distribution and availability. J. Trop. Ecol. 25, 563-567. doi: 10.1017/S0266467409990137

Casewell, N. R., Wüster, W., Vonk, F. J., Harrison, R. A., and Fry, B. G. (2013). Complex cocktails: the evolutionary novelty of venoms. Trends Ecol. Evol. 28, 219-229. doi: 10.1016/j.tree.2012.10.020

Cavalcanti, S. M. C., Crawshaw, P. G. J., Pires, L., Santiago, M. E. B., and Rech, T. C. (2016). Predation of an adult puma by an anaconda in south-eastern Brazil. Cat News 63, 5-6.

Cedillo-Leal, C. N., Alvarez, F., Casas-Andreu, G., Escobedo-Galván, A. H., and Barrios-Quiroz, G. (2013). Occurrence of Amphibalanus venustus (Darwin, 1854) (Cirripedia, Balanidae) on Trachemys venusta cataspila (Reptilia, Testudines) in Tamaulipas, Mexico. Crustaceana 86, 1711-1714. doi: 10.1163/15685403-00003239

Chamorro, S., Heleno, R., Olesen, J. M., McMullen, C. K., and Traveset, A. (2012). Pollination patterns and plant breeding systems in the Galápagos: a review. Ann. Bot. 110, 1489-1501. doi: 10.1093/aob/mcs132

Chinchilla, F. (1997). La dieta del jaguar (Panthera onca), el puma (Fells concolor) y el manigordo (Felis pardalis)(Carnivora; Felidae) en el Parque Nacional Corcovado, Costa Rica. Rev. Biol. Trop. 45, 1223-1230.

Colléony, A., Clayton, S., Couvet, D., Saint Jalme, M., and Prévot, A.-C. (2017). Human preferences for species conservation: animal charisma trumps endangered status. Biol. Conserv. 206, 263-269. doi: 10.1016/j.biocon.2016.11.035 
Cook, E. G., Murphy, T. G., and Johnson, M. A. (2013). Colorful displays signal male quality in a tropical anole lizard. Naturwissenschaften 100, 993-996. doi: 10.1007/s00114-013-1095-5

Corlett, R. (2011). Vertebrate carnivores and predation in the oriental (Indomalayan) region. Raffles Bull. Zool. 59, 325-360.

Cott, H. B. (1961). Scientific results of an inquiry into the ecology and economic status of the Nile crocodile, Crocodylus niloticus, in Uganda and northern Rhodesia. Lond. Trans. Zool. Soc. 29, 211-337. doi: 10.1111/j.1096-3642.1961.tb00220.x

Cupul-Magaña, F. (2011). First report of the marine barnacles Lepas anatifera and Chelonibia testudinaria as epibionts on American crocodile (Crocodylus acutus). Herpetol. Notes 4, 213-214.

Dalhuijsen, K., Branch, W. R., and Alexander, G. J. (2015). A comparative analysis of the diets of Varanus albigularis and Varanus niloticus in South Africa. Afr. Zool. 49, 83-93. doi: 10.1080/15627020.2014.11407621

Darimont, C. T., Fox, C. H., Bryan, H. M., and Reimchen, T. E. (2015). The unique ecology of human predators. Science 349, 855-860. doi: 10.1126/science.aac4249

Da Silveira, R., Ramalho, E. E., Thorbjarnarson, J. B., and Magnusson, W. E. (2010). Depredation by jaguars on caimans and importance of reptiles in the diet of jaguar. J. Herpetol. 44, 418-424. doi: 10.1670/08-340.1

de Castro, E. R., and Galetti, M. (2004). Frugivory and seed dispersal by the tegu lizard Tupinambis merianae Reptilia: teiidae. Papéis Avulsos Zool. 44, 91-97. doi: 10.1590/S0031-10492004000600001

Deitz, D., and Hines, T. (1980). Alligator nesting in north-central Florida. Copeia 2, 249-258. doi: 10.2307/1444001

Devaux, B. (2000). La Tortue Qui Pleure - The Crying Tortoise Geochelone Sulcata. Gonfaron: SOPTOM. Available online at: http://bibliotheques.mnhn. $\mathrm{fr} /$ medias/detailstatic.aspx?INSTANCE=EXPLOITATION\&RSC_BASE= HORIZON\&RSC_DOCID=413621 (Accessed January 3, 2016).

Diamond, J. (1998). Guns, Germs, and Steel: A Short History of Everybody for the Last 13,000 Years. Available online at: https://scholar.google.com.br/scholar?q= diamond+guns+germs+and+steel\&hl=pt-BR\&as_sdt=0,5\#1 (Accessed August 2, 2015).

Ding, Y.-Z. , Wang, X.-M. , He, L.-J. , Shao, M., Xie, W.-S. , Thorbjarnarson, B. J., et al. (2001). Study on the current population and habitat of the wild Chinese alligator (Alligator sinensis). Chin. Biodivers. 9, 102-108.

Doody, J. S. (2009). Eyes bigger than stomach: prey caching and retrieval in the saltwater crocodile, Crocodylus porosus. Herpetol. Rev. 40, 26.

Doody, S. J., Sims, R. A., and Letnic, M. (2007). Environmental manipulation to avoid a unique predator: drinking hole excavation in the agile wallaby, Macropus agilis. Ethology 113, 128-136. doi: 10.1111/j.1439-0310.2006.01298.x

Dorcas, M. E., Willson, J. D., Reed, R. N., Snow, R. W., Rochford, M. R., Miller, M. A., et al. (2012). Severe mammal declines coincide with proliferation of invasive Burmese pythons in Everglades National Park. Proc. Natl. Acad. Sci. U.S.A. 109, 2418-2422. doi: 10.1073/pnas.1115226109

Doughty, C. E., Roman, J., Faurby, S., Wolf, A., Haque, A., Bakker, E. S., et al. (2015). Global nutrient transport in a world of giants. Proc. Natl. Acad. Sci. U.S.A. 113, 868-873. doi: 10.1073/pnas.1502549112

Elgar, M. A., and Heaphy, L. J. (1989). Covariation between clutch size, egg weight and egg shape: comparative evidence for chelonians. J. Zool. 219, 137-152. doi: 10.1111/j.1469-7998.1989.tb02572.x

Elsey, R. M., Will, S., King, R., Miller, M., and Platt, S. G. (2013). Alligator mississipiensis (American Alligator) nests used by other species in coastal Louisiana. Herpetol. Rev. 44, 659-660.

Emmons, L. H. (1987). Comparative feeding ecology of felids in a neotropical rainforest. Behav. Ecol. Sociobiol. 20, 271-283. doi: 10.1007/BF00292180

Erickson, G. M., Gignac, P. M., Steppan, S. J., Lappin, A. K., Vliet, K. A., Brueggen, J. D., et al. (2012). Insights into the ecology and evolutionary success of crocodilians revealed through bite-force and tooth-pressure experimentation. PLoS ONE 7:e31781. doi: 10.1371/journal.pone.0031781

Ferreira, S. M., and Pienaar, D. (2011). Degradation of the crocodile population in the Olifants River gorge of Kruger National Park, South Africa. Mar. Freshw. Ecosyst. 21, 155-164. doi: 10.1002/aqc.1175

Flannery, T. (2002). The Future Eaters: An Ecological History of the Australasian Lands and People. Grove Press. Available online at: https://books.google.com.br/books?hl=pt-BR\&lr=\&id=eIW5aktgo0IC\&oi=fnd
$\& p g=P A 5 \& d q=$ The + future + eaters + flannery\&ots $=$ QZ1WglRTRR\&sig $=$ GsTjdq -Pq8LhrIQpMgSnIeGzNhY (Accessed December 15, 2015).

Fredriksson, G. M. (2005). Predation on sun bears by reticulated python in East Kalimantan, Indonesian Borneo. Raffles Bull. Zool. 53, 197-200.

Frick, M. G., Williams, K. L., Markesteyn, E. J., Pfaller, J. B., and Frick, R. E. (2004). New records and observations of epibionts from loggerhead sea turtles. Southeast. Nat. 3, 613-620. doi: 10.1656/15287092(2004)003[0613:NRAOOE]2.0.CO;2

Fricke, E. C., Simon, M. J., Reagan, K. M., Levey, D. J., Riffell, J. A., Carlo, T. A., et al. (2013). When condition trumps location: seed consumption by fruit-eating birds removes pathogens and predator attractants. Ecol. Lett. 16, 1031-1036. doi: 10.1111/ele.12134

Froyd, C. A., Coffey, E. E., van der Knaap, W. O., Leeuwen, J. F., Tye, A., and Willis, K. J. (2014). The ecological consequences of megafaunal loss: giant tortoises and wetland biodiversity. Ecol. Lett. 17, 144-154. doi: 10.1111/ele.12203

Fulgione, D., Trapanese, M., Maselli, V., Rippa, D., Itri, F., Avallone, B., et al. (2014). Seeing through the skin: dermal light sensitivity provides cryptism in moorish gecko. J. Zool. 294, 122-128. doi: 10.1111/jzo.12159

Gaulke, M., and Demegillo, A. (2008). The Mabitang: large fruit-eating monitor of the Philippines-Varanus mabitang. Reptilia 59, 39-46.

Gibbs, J. P., Sterling, E. J., and Zabala, F. J. (2010). Giant tortoises as ecological engineers: a long-term quasi-experiment in the Galápagos Islands. Biotropica 42, 208-214. doi: 10.1111/j.1744-7429.2009.00552.x

Godínez-Alvarez, H. (2004). Pollination and seed dispersal by lizards: a review. Rev. Chil. Hist. Nat. 77, 569-577. doi: 10.4067/S0716-078X2004000 300015

González-Castro, A., Calviño-Cancela, M., and Nogales, M. (2015). Comparing seed dispersal effectiveness by frugivores at the community level. Ecology 96, 808-818. doi: 10.1890/14-0655.1

Goursi, U., Awan, M., Minhas, R., Ali, U., Kabir, M., and Dar, N. (2012). Status and Conservation of Indian Rock Python (Python molurus molurus) in Deva Vatala National Park, Azad Jammu and Kashmir, Pakistan. Pak. J. Zool. 44, 1507-1514.

Green, R. E., Braun, E. L., Armstrong, J., Earl, D., Nguyen, N., Hickey, G., et al. (2014). Three crocodilian genomes reveal ancestral patterns of evolution among archosaurs. Science 346:1254449. doi: 10.1126/science.12 54449

Guilder, J., Barca, B., Arroyo-Arce, S., Gramajo, R., and Salom-Pérez, R. (2015). Jaguars (Panthera onca) increase kill utilization rates and share prey in response to seasonal fluctuations in nesting green turtle (Chelonia mydas mydas) abundance in Tortuguero National Park, Costa Rica. Mamm. Biol. 80, 65-72. doi: 10.1016/j.mambio.2014.11.005

Hailey, A., Chidavaenzi, R. L., and Loveridge, J. P. (1998). Diet mixing in the omnivorous tortoise Kinixys spekii. Funct. Ecol. 12, 373-385. doi: 10.1046/j.1365-2435.1998.00203.x

Hamann, O. (1993). On vegetation recovery, goats and giant tortoises on Pinta Island, Galápagos, Ecuador. Biodivers. Conserv. 2, 138-151. doi: $10.1007 / B F 00056130$

Hannan, L. B., Roth, J. D., Ehrhart, L. M., and Weishampel, J. F. (2007) Dune vegetation fertilization by nesting sea turtles. Ecology 88, 1053-1058. doi: 10.1890/06-0629

Hansen, D. M., Beer, K., and Müller, C. B. (2006). Mauritian coloured nectar no longer a mystery: a visual signal for lizard pollinators. Biol. Lett. 2, 165-168. doi: 10.1098/rsbl.2006.0458

Hansen, D. M., Donlan, C. J., Griffiths, C. J., and Campbell, K. J. (2010). Ecological history and latent conservation potential: large and giant tortoises as a model for taxon substitutions. Ecography 33, 272-284. doi: 10.1111/j.1600-0587.2010.06305.x

Hanson, J. O., Salisbury, S. W., Campbell, H. A., Dwyer, R. G., Jardine, T. D., and Franklin, C. E. (2015). Feeding across the food web: the interaction between diet, movement and body size in estuarine crocodiles (Crocodylus porosus). Austral. Ecol. 40, 275-286. doi: 10.1111/aec.12212

Hayashi, R. (2012). A checklist of turtle and whale barnacles (Cirripedia: Thoracica: Coronuloidea). J. Mar. Biol. Assoc. U.K. 93, 143-182. doi: 10.1017/S0025315412000847

Hayashi, R., and Tsuji, K. (2007). Spatial distribution of turtle barnacles on the green sea turtle, Chelonia mydas. Ecol. Res. 23, 121-125. doi: 10.1007/s11284-007-0349-0 
Hays, G. C., and Scott, R. (2013). Global patterns for upper ceilings on migration distance in sea turtles and comparisons with fish, birds and mammals. Funct. Ecol. 27, 748-756. doi: 10.1111/1365-2435.12073

Heithaus, M. R., Alcoverro, T., Arthur, R., Burkholder, D. A., Coates, K. A., Christianen, M. J. A., et al. (2014). Seagrasses in the age of sea turtle conservation and shark overfishing. Front. Mar. Sci. 1:28. doi: $10.3389 /$ fmars. 2014.00028

Helfield, J. M., and Naiman, R. J. (2001). Effects of salmon-derived nitrogen on riparian forest growth adn implications for stream productivity. Ecology 82, 2403-2409. doi: 10.1890/0012-9658(2001)082[2403:EOSDNO] 2.0.CO;2

Hernández, O., and Espinosa-Blanco, A. (2010). Artificial incubation of yellowheaded sideneck turtle Podocnemis unifilis eggs to reduce losses to flooding and predation, Cojedes and Manapire Rivers. Conserv. Evid. 7, 100-105.

Hirayama, R., Sonoda, T., Takai, M., Htike, T., Thein, Z. M. M., and Takahashi, A. (2015). Megalochelys: gigantic tortoise from the Neogene of Myanmar. PeerJ Prepr. 3:e1185. doi: 10.7287/PEERJ.PREPRINTS.961

Hocknull, S. A., Piper, P. J., van den Bergh, G. D., Due, R. A., Morwood, M. J., and Kurniawan, I. (2009). Dragon's paradise lost: palaeobiogeography, evolution and extinction of the largest-ever terrestrial lizards (Varanidae). PLoS ONE 4:e7241. doi: 10.1371/journal.pone.0007241

Holloway, R. H. (2003). Natural History Notes on the River Terrapin Batagur baska (Gray, 1831) in Cambodia. New York, NY: Research Development Program.

Hopkins, H. C. F., Bradford, J. C., Donovan, B., Pillon, Y., Munzinger, J., and Fogliani, B. (2015). Floral biology of the Cunoniaceae in New Caledonia and the role of insects, birds and geckos as potential pollinators. Kew Bull. 70:8. doi: $10.1007 / \mathrm{s} 12225-014-9546-5$

Hutton, J. M. (1987). Growth and feeding ecology of the nile crocodile Crocodylus niloticus at Ngezi, Zimbabwe. J. Anim. Ecol. 56, 25-38. doi: 10.2307/4797

Irwin, G., Worthy, T. H., Best, S., Hawkins, S., Carpenter, J., and Matararaba, S. (2011). Further investigations at the naigani lapita site (VL 21/5), Fiji: excavation, radiocarbon dating and palaeofaunal extinction. J. Pac. Archaeol. $2,66-78$.

IUCN (1996). Centrochelys sulcata (African Spurred Tortoise, Grooved Tortoise). Available online at: http://www.iucnredlist.org/details/163423/0 (Accessed January 5, 2016)

IUCN (2000). Manouria emys: e.T12774A3380771. IUCN Red List Threat. Species/Asian Turt. Trade Work. Gr. doi: 10.2305/IUCN.UK.2000.RLTS. T12774A3380771.en (Accessed August 3, 2016).

Jorge, M., and Galetti, M. (2013). Mammal defaunation as surrogate of trophic cascades in a biodiversity hotspot. Biol. Conserv. 163, 49-57. doi: 10.1016/j.biocon.2013.04.018

Keller, M. (2005). The Nile Soft-Shelled Turtle Trionyx triunguis in Turkey, An Overview. Munich: AgA International.

Kinaston, R., Bedford, S., Richards, M., Hawkins, S., Gray, A., Jaouen, K., et al. (2014). Diet and human mobility from the lapita to the early historic period on Uripiv island, Northeast Malakula, Vanuatu. PLoS ONE 9:e104071. doi: 10.1371/journal.pone.0104071

King, D. (1980). The thermal biology of free-living sand goannas (Varanus gouldii) in southern Australia. Copeia 1980, 755-767. doi: 10.2307/1444454

Kinlaw, A. (1999). A review of burrowing by semi-fossorial vertebrates in arid environments. J. Arid. Environ. 41, 127-145. doi: 10.1006/jare.1998.0476

Kinlaw, A., and Grasmueck, M. (2012). Evidence for and geomorphologic consequences of a reptilian ecosystem engineer: the burrowing cascade initiated by the Gopher Tortoise. Geomorphology 157-158, 108-121. doi: 10.1016/j.geomorph.2011.06.030

Kofron, C. P. (1989). Nesting ecology of the Nile crocodile (Crocodylus niloticus). Afr. J. Ecol. 27, 335-341. doi: 10.1111/j.1365-2028.1989.tb01027.x

Kordges, T. (1998). Die Reptilienfauna des Thumama Nature Park bei Riyadh, Saudi Arabien. Faun. Abhandlungen Staatl. Museum für Tierkd. Dresden 21, 67-83.

Kormann, U., Scherber, C., Tscharntke, T., Klein, N., Larbig, M., Valente, J. J., et al. (2016). Corridors restore animal-mediated pollination in fragmented tropical forest landscape. Proc. R. Soc. B Biol. Sci. 283, 1-8. doi: 10.1098/rspb.2015.2347

Kubitzki, K., and Ziburski, A. (1994). Seed dispersal in flood plain forests of Amazonia. Biotropica 26, 30-43. doi: 10.2307/2389108

Kushlan, J., and Kushlan, M. (1980). Everglades alligator nests: nesting sites for marsh reptiles. Copeia 4, 930-932. doi: 10.2307/1444493
Lambert, F. R., and Howes, J. R. (1994). Ranging, breeding behaviour and food of the Asian brown tortoise Manouria emys in Borneo. Malayan Nat. J. 48, 125-131.

Lazo-Wasem, E. A., Pinou, T., Peña de Niz, A., and Feuerstein, A. (2011). Epibionts associated with the nesting marine turtles Lepidochelys olivacea and Chelonia mydas in Jalisco, Mexico: a review and field guide. Bull. Peabody Museum Nat. Hist. 52, 221-240. doi: 10.3374/014.052.0203

Leopold, A. (1949). A Sand County Almanac, and Sketches Here and There. Oxford: Oxford University Press.

Lomolino, M. V., Channell, R., Perault, D. R., and Smith, G. A. (2001). "Downsizing nature: anthropogenic dwarfing of species and ecosystems," in Biotic Homogenization, eds J. L. Lockwood and M. L. McKinney (Boston, MA: Springer), 223-243. doi: 10.1007/978-1-4615-1261-5_11 (Accessed January 7, 2016).

Maffei, F., and Da Silveira, R. (2013). First record of multiple nests of yellow-spotted river turtle (Podocnemis unifilis) in a nest of black caiman Melanosuchus. Bol. Mus. Para. Emílio Goeldi 8, 2013.

Makarieva, A. M., Gorshkov, V. G., and Li, B. L. (2005). Gigantism, temperature and metabolic rate in terrestrial poikilotherms. Proc. R. Soc. B Biol. Sci. 272, 2325-2328. doi: 10.1098/rspb.2005.3223

Malhia, Y., Doughty, C. E., Galetti, M., Smith, F. A., Svenning, J. C., and Terborgh, J. W. (2016). Megafauna and ecosystem function from the Pleistocene to the Anthropocene. Proc. Natl. Acad. Sci. U.S.A. 113, 838-846. doi: 10.1073/pnas.1502540113

Mason, M. C., Kerley, G. I. H., Weathreby, C. A., and Branch, W. R. (2000). Angulate and leopard tortoises in the Thicket Biome, Eastern Cape, South Africa: populations and biomass estimates. Afr. J. Ecol. 38, 147-153. doi: 10.1046/j.1365-2028.2000.00231.x

McCleery, R. A., Sovie, A., Reed, R. N., Cunningham, M. W., Hunter, M. E., and Hart, K. M. (2015). Marsh rabbit mortalities tie pythons to the precipitous decline of mammals in the Everglades. Proc. R. Soc. Lond. B Biol. Sci. 282:20150120. doi: 10.1098/rspb.2015.0120

McGuire, J. A., and Dudley, R. (2011). The biology of gliding in flying lizards (genus Draco) and their fossil and extant analogs. Integr. Comp. Biol. 51, 983-990. doi: 10.1093/icb/icr090

McIntosh, R. (1986). The Background of Ecology: Concept and Theory. Cambridge: Cambridge University Press. Available online at: https://books.google.com br/books?hl=pt-BR\&lr=\&id=1bYSnG7RITAC\&oi=fnd\&pg=PR9\&dq=The+ Background+of+Ecology:+Concept+and+Theory\&ots=kotdaoxzxm\&sig= Pf6Pv6hfUUGhNy5L_QeKymqwiLo (Accessed November 15, 2015).

Mead, J. I., Steadman, D. W., Bedford, S. H., Bell, C. J., and Spriggs, M. (2009) New extinct mekosuchine crocodile from Vanuatu, South Pacific. Copeia 2002, 632-641. doi: 10.1643/0045-8511(2002)002\%5B0632:NEMCFV\%5D2.0.CO;2

Meehan, H. J., McConkey, K. R., and Drake, D. R. (2002). Potential disruptions to seed dispersal mutualisms in Tonga, Western Polynesia. J. Biogeogr. 29, 695-712. doi: 10.1046/j.1365-2699.2002.00718.x

Miller, J. (1997). "Reproduction in sea turtles," in The Biology of Sea Turtles, eds P. L. Lutz and J. A. Musick (Boca Ratón, FL: CRC Press), 51-80. Available online at: https://scholar.google.com.br/scholar?q=Miller\%2C+J.D. $\% 2 \mathrm{C}+$ Reproduction+in+sea+turtles $\% 2 \mathrm{C}+\mathrm{in}+\mathrm{The}+\mathrm{Biology}+\mathrm{of}+\mathrm{Sea}+$ Turtles $\&$ btnG=\&hl=pt-BR\&as_sdt=0\%2C5\&as_ylo=1997\&as_yhi=1997\#0 （Accessed November 28, 2015).

Milton, S. (1992). Plants eaten and dispersed by adult leopard tortoises Geochelone pardalis (Reptilia: Chelonii) in the southern Karoo. S. Afr. J. Zool. 27, 45-49. doi: 10.1080/02541858.1992.11448261

Miorando, P. S., Giarrizzo, T., and Pezzuti, J. C. (2015). Population structure and allometry of Podocnemis unifilis (Testudines, Podocnemididae) in a protected area upstream Belo Monte dam in Xingu River, Brazil. Ann. Acad. Bras. Cienc. 87, 2067-2079. doi: 10.1590/0001-3765201520140321

Miranda, E. B. P., Ribeiro, R. P. Jr., and Strüssmann, C. (2016). The ecology of human-anaconda conflict: a study using internet videos. Trop. Conserv. Sci. 9, 26-60. doi: 10.1177/194008291600900105

Moll, D., and Jansen, K. (1995). Evidence for a role in seed dispersal by two tropical herbivorous turtles. Biotropica 27, 121-127. doi: 10.2307/2388909

Molnar, R. (2004). Dragons in the Dust: The Paleobiology of the Giant Monitor Lizard Megalania. Available online at: https://books.google.com.br/books? $\mathrm{hl}=\mathrm{pt}-\mathrm{BR} \& \mathrm{lr}=\& \mathrm{id}=$ AvPHRQYqEcQC\&oi=fnd\&pg=PR9\&dq=Dragons $+\mathrm{in}+$ the+dust:+the+paleobiology+of+the+giant+monitor+lizard+Megalania\&ots= 
1yLamBxUKh\&sig=tt8uaoEcRYSQiPM7aNfnVFLGyTQ (Accessed December $28,2016)$.

Monroe, R., and Garrett, R. (1979). Chelonibia testudinaria (L.) (Cirripedia, Coronulidae) on Crocodylus porosus Schneider, a new host record. Crustaceana $36,108$.

Moolna, A. (2008). Preliminary observations indicate that giant tortoise ingestion improves seed germination for an endemic ebony species in Mauritius. Afr. J. Ecol. 46, 217-219. doi: 10.1111/j.1365-2028.2007.00807.x

Moran, K. L., and Bjorndal, K. A. (2005). Simulated green turtle grazing affects structure and productivity of seagrass pastures. Mar. Ecol. Prog. Ser. 305, 235-247. doi: 10.3354/meps305235

Moskovits, D. (1988). Sexual dimorphism and population estimates of the two Amazonian tortoises (Geochelone carbonaria and G. denticulata) in northwestern Brazil. Herpetologica 44, 209-217.

Mukherjee, S., and Sarkar, N., Sen (2013). The range of prey size of the Royal Bengal Tiger of Sundarbans. J. Ecosyst. 1, 1-7. doi: 10.1155/2013/351756

Munoz, E. M., Ortega, A. M., Bock, B. C., and Páez, V. P. (2003). Demografía y ecología de anidación de la iguana verde, Iguana iguana (Squamata: Iguanidae), en dos poblaciones explotadas en la Depresión Momposina, Colombia. Int. J. Trop. Biol. Conserv. 51, 229-240.

Natusch, D. J., Lyons, J. A., Riyanto, A., and Shine, R. (2016). Jungle giants: assessing sustainable harvesting in a difficult-to-survey species (Python reticulatus. PLoS ONE 11:e0158397. doi: 10.1371/journal.pone.0158397

Nell, L. A., and Frederick, P. C. (2015). Fallen nestlings and regurgitant as mechanisms of nutrient transfer from nesting wading birds to crocodilians. Wetlands 35, 723-732. doi: 10.1007/s13157-015-0664-0

Nifong, J. C., and Frick, M. G. (2011). First record of the American alligator (Alligator mississippiensis) as a host to the sea Turtle Barnacle (Chelonibia testudinaria). Southeast. Nat. 10, 557-560. doi: 10.1656/058.010.0316

Nifong, J., and Silliman, B. (2013). Impacts of a large-bodied, apex predator (Alligator mississippiensis Daudin 1801) on salt marsh food webs. J. Exp. Mar. Biol. Ecol. 440, 185-191. doi: 10.1016/j.jembe.2013.01.002

Olesen, J. M., and Valido, A. (2003). Lizards as pollinators and seed dispersers: an island phenomenon. Trends Ecol. Evol. 18, 177-181. doi: 10.1016/S0169-5347(03)00004-1

Pain, D. J., Cunningham, A. A., Donald, P. F., Duckworth, J. W., Houston, D. C., Katzner, T., et al. (2003). Causes and effects of temporospatial declines of gyps vultures in asia. Conserv. Biol. 17, 661-671. doi: 10.1046/j.1523-1739.2003. 01740.x

Palmer, M. L., and Mazzotti, F. J. (2004). Structure of everglades alligator holes. Wetlands 24, 115-122. doi: 10.1672/02775212(2004)024\%5B0115:SOEAH\%5D2.0.CO;2

Patten, M. A., and Bolger, D. T. (2003). Variation in top-down control of avian reproductive success across a fragmentation gradient. Oikos 101, 479-488. doi: 10.1034/j.1600-0706.2003.12515.x

Pauly, D. (1995). Anecdotes and the shifting baseline syndrome of fisheries. Trends Ecol. Evol. (Amst). 10, 430. doi: 10.1016/S0169-5347(00)89171-5

Pfaller, J. B., Frick, M. G., Brischoux, F., Sheehy, C. M., and Lillywhite, H. B. (2012). Marine snake epibiosis: a review and first report of decapods associated with Pelamis platurus. Integr. Comp. Biol. 52, 296-310. doi: 10.1093/icb/ics038

Pinou, T., Lazo-Wasem, E. A., Dion, K., and Zardus, J. D. (2013). Six degrees of separation in barnacles? Assessing genetic variability in the sea-turtle epibiont Stomatolepas elegans (Costa) among turtles, beaches and oceans. J. Nat. Hist. 47, 2193-2212. doi: 10.1080/00222933.2013.798701

Platt, S. G., Rainwater, T. R., Thorbjarnarson, J. B., and McMurry, S. T. (2008). Reproductive dynamics of a tropical freshwater crocodilian: morelet's crocodile in northern Belize. J. Zool. 275, 177-189. doi: 10.1111/j.1469-7998.2008.00426.x

Pritchard, P. (1996). The Galápagos Tortoises: Nomenclatural and Survival Status. Lunenburg, NS: Chelonian Research Foundation in association with Conservation International and Chelonia Institute. Available online at: https://scholar.google.com.br/scholar?q=The+Galapagos+tortoises\%3A+ nomenclatural+and+survival+status\&btnG $=\& \mathrm{hl}=\mathrm{pt}-\mathrm{BR} \& \mathrm{as} \_\mathrm{sdt}=0 \% 2 \mathrm{C} 5 \# 0$ (Accessed January 7, 2016).

Pritchard, P. C., and Trebbau, P. (1984). The Turtles of Venezuela. Oxford: Society for the Study of Amphibians and Reptiles.

Regalado, P. G. (2015). Los Anfibios y Reptiles Extinguidos: Herpetofauna Desaparecida Desde el Año 1500. Coruña: Universidade da Coruña, Servizo de Publicacións.
Rhodin, A. G. J., Thomson, S., Georgalis, G. L., Karl, H.-V., Danilov, I. G., Takahashi, A., et al. (2015). Turtles and tortoises of the world during the rise and global spread of humanity: first checklist and review of extinct pleistocene and holocene chelonians. Chelonian Res. Monogr. 5, 000e.1-000e.66. doi: 10.3854/crm.5.000e.fossil.checklist.v1.2015

Rhodin, A. G. J., Walde, A. D., Horne, B. D., Van Dijk, P. P., Blanck, T., and Hudson, R. (2011). Turtles in Trouble: The World's 25+ Most Endangered Tortoises and Freshwater Turtles. Public, 54. Available online at: http://www. turtlesurvival.org/storage/documents/top_25_turtles_in_trouble_2011.pdf

Richmond, J. Q., Wood, D. A., Stanford, J. W., and Fisher, R. N. (2014). Testing for multiple invasion routes and source populations for the invasive brown treesnake (Boiga irregularis) on Guam: implications for pest management. Biol. Invasions 17, 337-349. doi: 10.1007/s10530-014-0733-y

Roberts, R. G., Jones, R., Spooner, N. A., Head, M. J., Murray, A. S., and Smith, M. A. (1994). The human colonisation of Australia: optical dates of 53,000 and 60,000 years bracket human arrival at Deaf Adder Gorge, Northern Territory. Quat. Sci. Rev. 13, 575-583. doi: 10.1016/0277-3791(94)90080-9

Rodda, G. H., Perry, G. A. D., Rondeau, R. J., and Lazell, J. (2001). The densest terrestrial vertebrate. J. Trop. Ecol. 17, 331-338. doi: $10.1017 /$ S0266467401001225

Samson, F. B., and Knopf, F. L. (1996). Ecosystem Management. New York, NY: Springer.

Sazima, I., and D’Angelo, G. B. (2013). Range of animal food types recorded for the tegu lizard (Salvator merianae) at an urban park in South-eastern Brazil. Herpetol. Notes 6, 427-430.

Sazima, I., Sazima, C., and Sazima, M. (2005). Little dragons prefer flowers to maidens: a lizard that laps nectar and pollinates trees. Biota Neotrop. 5, 185-192. doi: 10.1590/S1676-06032005000100018

Scognamillo, D., Maxit, I. E., Sunquist, M., and Polisar, J. (2003). Coexistence of jaguar (Panthera onca) and puma (Puma concolor) in a mosaic landscape in the Venezuelan llanos. J. Zool. 259, 269-279. doi: 10.1017/S09528369020 03230

Seigel, R. (1983). Occurrence and effects of barnacle infestations on diamondback terrapins (Malaclemys terrapin). Am. Midl. Nat. 109, 34-39. doi: $10.2307 / 2425512$

Shankar, P. G., Singh, A., Ganesh, S. R., and Whitaker, R. (2013). Factors influencing human hostility to King Cobras (Ophiophagus hannah) in the Western Ghats of India. Hamadryad 36, 91-100.

Shine, R., and Harlow, P. S. (1998). Ecological traits of commercially harvested water monitors, Varanus salvator, in northern Sumatra. Wildl. Res. 25, 437. doi: 10.1071/WR97118

Shine, R., Harlow, P. S. P., and Keogh, J. S. (1998). The influence of sex and body size on food habits of a giant tropical snake, Python reticulatus. Funct. Ecol. 12, 248-258. doi: 10.1046/j.1365-2435.1998.00179.x

Shine, R., Harlow, P. S., and Keogh, J. S. (1996). Commercial harvesting of giant lizards: the biology of water monitors Varanus salvator in southern Sumatra. Biol. Conserv. 77, 125-134. doi: 10.1016/0006-3207(96)00008-0

Slavenko, A., Tallowin, O. J. S., Itescu, Y., Raia, P., and Meiri, S. (2016). Late Quaternary reptile extinctions: size matters, insularity dominates. Glob. Ecol. Biogeogr. 25, 1308-1320. doi: 10.1111/geb.12491

Smith, N. J. H. (1979). Aquatic turtles of Amazonia: an endangered resource. Biol. Conserv. 16, 165-176. doi: 10.1016/0006-3207(79)90019-3

Sobbe, I. H., Price, G. J., and Knezour, R. A. (2013). A ziphodont crocodile from the late Pleistocene King Creek catchment, Darling Downs, Queensland. Mem. Queensl. Museum Nat. 56, 601-606.

Sobral-Souza, T., Lautenschlager, L., Morcatty, T. Q., Bello, C., Hansen, D., and Galetti, M. (2017). Rewilding defaunated Atlantic Forests with tortoises to restore lost seed dispersal functions. Perspect. Ecol. Conserv. 15, 300-307. doi: 10.1016/j.pecon.2017.08.005

Somaweera, R., Webb, J. K., and Shine, R. (2011). It's a dog-eat-croc world: dingo predation on the nests of freshwater crocodiles in tropical Australia. Ecol. Res. 26, 957-967. doi: 10.1007/s11284-011-0853-0

Spotila, J. (2004). Sea Turtles: A Complete Guide to Their Biology, Behavior, and Conservation. Baltimore, MD: JHU Press. Available online at: https:// books.google.com.br/books?hl=pt-BR\&lr=\&id=dpsJrFxVIvUC\&oi=fnd\&pg= PP15\&dq=+Sea+Turtles:+a+Complete+Guide+to+their+Biology, +Behavior, + and+Conservation\&ots=t66ogI1Mna\&sig=CZeICIt20SjarQi1cic0YrSs43M (Accessed November 28, 2015). 
Stanford, C. B., Wanchai, P., Schaffer, C., Schaffer, R., and Thirakhupt, K. (2015). "Manouria emys (Schlegel and Müller 1840)-Asian giant tortoise, giant Asian forest tortoise," in Conservation Biology of Freshwater Turtles and Tortoises, Chelonian Research Monographs, eds A. G. J. Rhodin, J. B. Iverson, P. P. van Dijk, K. A. Buhlmann, P. C. H. Pritchard, R. A. Saumure, and R. A. Mittermeier (Lunenburg, NC: Chelonian Research Foundation), 1-86. doi: 10.3854/crm.5

Steadman, D. W., Albury, N. A., Kakuk, B., Mead, J. I., Soto-Centeno, J. A., Singleton, H. M., et al. (2015). Vertebrate community on an ice-age Caribbean island. Proc. Natl. Acad. Sci. U.S.A. 112:201516490. doi: 10.1073/pnas.1516490112

Stegmann, E. W., Primack, R. B., and Ellmore, G. S. (1988). Absorption of nutrient exudates from terrapin eggs by roots of Ammophila breviligulata (Gramineae). Can. J. Bot. 66, 714-718. doi: 10.1139/b88-103

Stevenson, C., and Whitaker, R. (2010). "Gharial Gavialis gangeticus," in Crocodiles. Status Survey and Conservation Action Plan, eds S. C. Manolis and C. Stevenson (Darwin, NT: Crocodile Specialist Group), 139-143.

Stevenson, J., Dodson, J., and Prosser, I. (2001). A late Quaternary record of environmental change and human impact from New Caledonia. Palaeogeogr. Palaeoclimatol. Palaeoecol. 168, 97-123. doi: 10.1016/S0031-0182(00)00251-0

Stewart, K., Matthiesen, D., Leblanc, L., and West, J. (1997). Prey diversity and selectivity of the African fish eagle: data from a roost in northern Kenya. Afr. J. Ecol. 35, 133-145. doi: 10.1111/j.1365-2028.1997.066-89066.x

Steyermark, A., Finkler, M., and Brooks, R. (2008). Biology of the Snapping Turtle (Chelydra serpentina). Baltimore, MD: Johns Hopkins University Press. Available online at: https://scholar.google.com.br/scholar?hl=pt-BR\& $\mathrm{q}=$ Biology+of + the + Snapping + Turtle $+\& b$ tn $G=\& l r=\# 2$ (Accessed December 12, 2015).

Stokstad, E. (1998). Popular interest fuels a dinosaur research boom. Science 282, 1246-1247. doi: $10.1126 /$ science.282.5392.1246

Strong, J., and Fragoso, J. (2006). Seed dispersal by Geochelone carbonaria and Geochelone denticulata in Northwestern Brazill. Biotropica 38, 683-686. doi: 10.1111/j.1744-7429.2006.00185.x

Subalusky, A. L., Dutton, C. L., Rosi, E. J., and Post, D. M. (2017). Annual mass drownings of the Serengeti wildebeest migration influence nutrient cycling and storage in the Mara River. Proc. Natl. Acad. Sci. U.S.A. 114, 7647-7652. doi: 10.1073/pnas.1614778114

Sutherland, D. R., Glen, A. S., and de Tores, P. J. (2011). Could controlling mammalian carnivores lead to mesopredator release of carnivorous reptiles? Proc. Biol. Sci. 278, 641-648. doi: 10.1098/rspb.2010.2103

Thorbjarnarson, J. (1999). Crocodile tears and skins: international trade, economic constraints, and limits to the sustainable use of crocodilians. Conserv. Biol. 13, 465-470. doi: 10.1046/j.1523-1739.1999.00011.x

Torralvo, K., Botero-Arias, R., and Magnusson, W. E. (2017). Temporal variation in black-caiman-nest predation in varzea of central Brazilian amazonia. PLoS ONE 12:e0183476. doi: 10.1371/journal.pone.0183476

Triep, M., Hess, D., Chaves, H., Brücker, C., Balmert, A., Westhoff, G., et al. (2013). $3 \mathrm{D}$ flow in the venom channel of a spitting cobra: do the ridges in the fangs act as fluid guide vanes? PLOS ONE 8:e61548. doi: 10.1371/journal.pone.0061548

Turvey, S. T., Almonte, J., Hansford, J., Scofield, R. P., Brocca, J. L., and Chapman, S. D. (2017). A new species of extinct Late Quaternary giant tortoise from Hispaniola. Zootaxa 4277, 1-16. doi: 10.11646/zootaxa.4277.1.1

Uetz, P., Freed, P., and Hošek, J. (2016). The Reptile Database. Available online at: http://www.reptile-database.org/db-info/SpeciesStat.html (Accessed October 19, 2017).

Valido, A., and Olesen, J. M. (2007). "The importance of lizards as frugivores and seed dispersers," in Seed Dispersal: Theory and Its Application in a Changing World, eds A. J. Dennis, E. W. Schupp, R. J. Green, and D. A. Westcott (Wallingford, CT: CAB International), 124-147.

Varela, R., and Bucher, E. (2002). Seed dispersal by Chelonoidis chilensis in the Chaco dry woodland of Argentina. J. Herpetol. 36, 137-140. doi: 10.1670/00221511(2002)036[0137:SDBCCI]2.0.CO;2
Vasconcelos, R., Brito, J. C., Carranza, S., and Harris, D. J. (2013). Review of the distribution and conservation status of the terrestrial reptiles of the Cape Verde Islands. Oryx 47, 77-87. doi: 10.1017/S00306053110 01438

Veríssimo, D., Jones, D., Chaverri, R., and Meyer, S. (2012). Jaguar Panthera onca predation of marine turtles: conflict between flagship species in Tortuguero, Costa Rica. Oryx 46, 340-347. doi: 10.1017/S0030605311 001487

Vitt, L. J., and Caldwell, J. P. (2013). Herpetology: An Introductory Biology of Amphibians and Reptiles. Cambridge: Academic Press.

Vranckx, G., Jacquemyn, H., Muys, B., and Honnay, O. (2012). Meta-analysis of susceptibility of woody plants to loss of genetic diversity through habitat fragmentation. Conserv. Biol. 26, 228-237. doi: 10.1111/j.1523-1739.2011.01778.x

Von Humboldt, A. (1877). Personal Narrative of Travels to the Equinoctial Regions of the New Continent During the Years 1799-1804. New York, NY: AMS Press. Available online at: https://scholar.google.com.br/scholar?q=humboldt+ Personal+narrative+of +travels+to+the+equinoctial+regions+of +the+New + Continent\&btnG=\&hl=pt-BR\&as_sdt=0\%2C5\#0 (Accessed September 21, 2015).

Whitaker, R., and Basu, D. (1982). The gharial (Gavialis gangeticus). J. Bombay Nat. Hist. Soc. 23, 531-548.

Whitaker, R., Barr, B., de Silva, A., and Ratnasiri, P. (2007). Observations on burrows dug by mugger crocodiles (Crocodylus palustris) in Bundala National Park, Sri Lanka. J. Bombay Nat. Hist. Soc. 104, 19-24.

Williams, J., Tieleman, B., and Shobrak, M. (1999). Lizard burrows provide thermal refugia for larks in the Arabian Desert. Condor 101, 714-717. doi: $10.2307 / 1370208$

Wilms, T., Eid, E. K. A., Al Johany, A. M. H., Amr, Z. S. S., Els, J., Baha El Din, S., et al. (2012). Uromastyx aegyptia. doi: 10.2305/IUCN.UK.2012.RLTS.T164729A1071308.en

Wilms, T., and Wagner, P. (2009). Activity profiles, habitat selection and seasonality of body weight in a population of Arabian Spiny-tailed Lizards (Uromastyx aegyptia microlepis Blanford, 1875; Sauria: Agamidae) in Saudi Arabia. Bonner Zool. 56, 259-272.

Wilms, T., Wagner, P., and Shobrak, M. (2010). Aspects of the ecology of the Arabian spiny-tailed lizard (Uromastyx aegyptia microlepis Blanford, 1875) at Mahazat as-Sayd protected area, Saudi Arabia. Salamandra 46, 131-140.

Wirsing, A. J., and Ripple, W. J. (2011). A comparison of shark and wolf research reveals similar behavioral responses by prey. Front. Ecol. Environ. 9, 335-341. doi: 10.1890/090226

Worthy, T., Anderson, A., and Molnar, R. (1999). Megafaunal expression in a land without mammals - the first fossil faunas from terrestrial deposits in Fiji. Senckenb. Biol. 79, 237-242.

Wroe, S., Myers, T. J., Wells, R. T., and Gillespie, A. (1999). Estimating the weight of the Pleistocene marsupial lion, Thylacoleo carnifex (Thylacoleonidae:Marsupialia): implications for the ecomorphology of a marsupial super-predator and hypotheses of impoverishment of Australian marsupial carnivore faunas. Aust. J. Zool. 47, 489. doi: 10.1071/ZO 99006

Conflict of Interest Statement: The author declares that the research was conducted in the absence of any commercial or financial relationships that could be construed as a potential conflict of interest.

Copyright (C) 2017 Miranda. This is an open-access article distributed under the terms of the Creative Commons Attribution License (CC BY). The use, distribution or reproduction in other forums is permitted, provided the original author(s) or licensor are credited and that the original publication in this journal is cited, in accordance with accepted academic practice. No use, distribution or reproduction is permitted which does not comply with these terms. 